Review Article

\title{
An Exhaustive Review on a Solar Still Coupled with a Flat Plate Collector
}

\author{
Ahmadreza Ayoobi $(\mathbb{D})$ and Mahdi Ramezanizadeh \\ Aerospace Engineering Department, Shahid Sattari Aeronautical University of Science and Technology, Tehran, Iran \\ Correspondence should be addressed to Ahmadreza Ayoobi; ar.ayoobi@ssau.ac.ir
}

Received 7 September 2021; Accepted 19 October 2021; Published 8 November 2021

Academic Editor: Mamdouh El Haj Assad

Copyright ( $) 2021$ Ahmadreza Ayoobi and Mahdi Ramezanizadeh. This is an open access article distributed under the Creative Commons Attribution License, which permits unrestricted use, distribution, and reproduction in any medium, provided the original work is properly cited.

\begin{abstract}
In recent years, producing energy and potable water has become a contemporaneous issue in all areas, especially in rural and remote areas. It is due to the limitation of fossil fuels in generating energy and the daily increase of potable water topic pollution due to various development activities in the industries. Gradually, the use of renewable energies has been suggested as far as humans focus on using these energies in various activities, which is gratis and accessible in more areas without having negative anthropogenic hazards. Solar radiation has an important position in renewable energies and has played a significant role in the desalination process due to the convenience in applying and abundance in the areas with potable water shortages. However, one of the active solar stills is the coupling of conventional solar still with a flat plate collector. In this type, a flat plate collector is used to raise the temperature of saline water which increases the productivity. In this research, the solar still coupled with a flat plate collector is reviewed as the active solar still and the affecting parameters on its performance and efficiency are discussed. First, a summary of working research and their research of flat plate collectors is reviewed to be more familiar with flat plate collectors, their details, and technology. Then, solar still coupled with a flat plate collector is extensively reviewed and discussed in detail. Four types of studies on solar still coupled with a flat plate collector were done, including energy analysis, exergy analysis, economic analysis, and productivity evaluation.
\end{abstract}

\section{Introduction}

Providing potable water for mankind's life is a critical topic that has continued until today as an important challenge. Because of the development of communities, the water demand in domestic, agriculture, industries, and etc. increases while potable water resources decrease. However, from the beginning until now, people in rural, remote, and arid areas are suffering from potable water shortage and waterborne diseases. It seems that a good solution is to desalinate the saline/sea water. Water desalination methods include multistage flash (MSF) [1], humidificationdehumidification (HDH) [2] vapor compression (VC) [3, 4], multieffect distillation (MED) [5-7], reverse osmosis (RO) [8], nanofiltration (NF) [9], and electrodialysis [10]. Potable water is mostly produced using fossil fuels, which has some drawbacks, including damage to the environment, increasing the global warming, high construction costs, heavy industrial equipment, and high energy consumption. A new alternate method for water desalination free from the abovementioned drawbacks is applying the renewable energies such as wind, solar, and earth. One of the suitable renewable energies for desalination is solar energy which is accessible in most of Earth's regions, and its application is easier than the other renewable energies. Also, it has less construction cost, less maintenance, and no need for a special operator and in general, it is cheaper, in comparison to the other renewable energy equipment.

To desalinate water by using solar energy, different methods, equipment, and configurations have been applied in both separate and hybrid methods such as a single slope $[11,12]$, having a solar collector [13-16], having sun tracking [17], pyramid shaped [18], pyramid with a collector [19] and others [20]. Many researchers investigated different methods and the operating parameters in various areas to find suitable conditions to obtain more freshwater and 


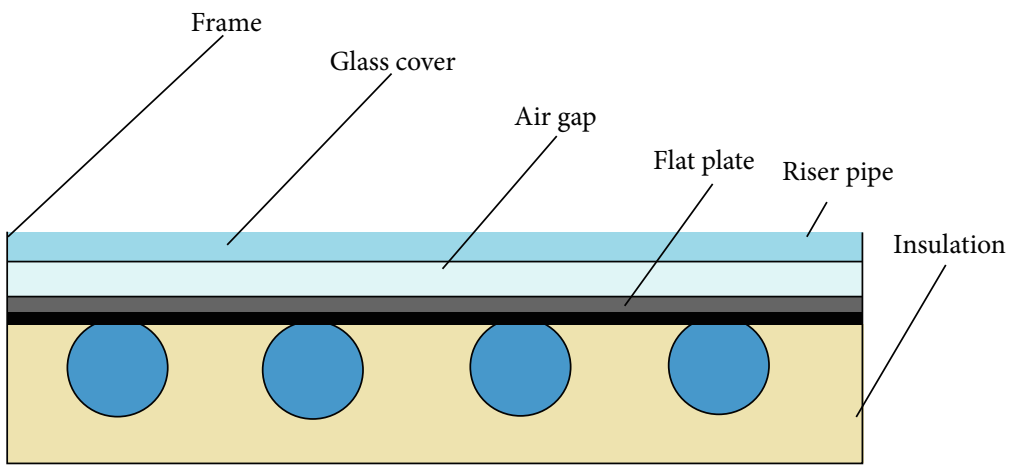

Figure 1: Schematic of a typical flat plate collector.

optimize the desalination systems. One of the applied solar desalination configurations is the desalination having the solar collector. That is, the solar still combines with a solar collector to increase the freshwater quantity. Several researchers have studied various scales, methods, areas, equipment, environmental conditions, and operating parameters in this regard.

The focus of this research is on solar still combined with a flat plate collector. In the next section, a short review of the solar flat plate collector investigations is presented to clarify its role and duty in the solar still. Then, a general explanation, main parameters, energy, exergy, economic analysis, important findings, and future pathway of the solar stills are investigated. Finally, based on the present study, suitable recommendations for future researches are presented.

\section{Solar Flat Plate Collector}

Due to fossil fuel limitations, application of the solar and the wind energies is increasing due to their easy access and low negative effects on the environment. Moreover, solar energy is preferred due to its low equipment cost, no need for special areas, easy maintenance, and abundant existence. The flat plate collector is a type of solar collectors which is highly applied due to easy construction and application (Figure 1). These are divided into two main categories including thermosiphon [21, 22] and force circulation [23-25]. A flat plate collector has different components including a glass cover [14, 26-28], absorber plate [29-31], air gap [32-35], riser pipe [36-40], frame, and insulation [41-43].

2.1. Absorber Plate. An absorber plate is preferred which is usually made of aluminum sheets, gets the solar energy in the form of radiation intensity, and transfers it to the riser pipes. It should be noted that receiving higher energy leads to higher efficiency. Therefore, its surface is painted with a black and matt color or is coated with a special material to increase absorption of the incidence energy.

Sakhaei and Valipour [29] investigated the effects of three different coatings of the absorber plate on the collector's thermal efficiency, including the black painting, the black chrome coating, and the carbon coating. Considering the different volume flow rates between 0.5 and $1.5 \mathrm{~L} \cdot \mathrm{min}^{-1}$, their results showed that the carbon coating has higher

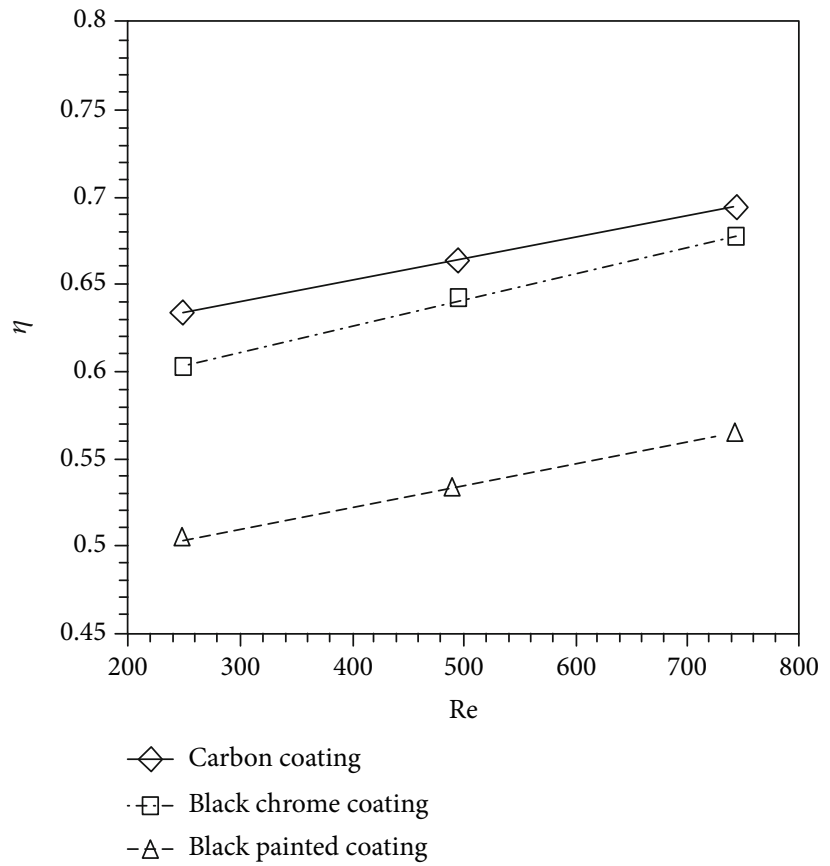

FIGURE 2: Effects of Reynolds number and coating materials on thermal efficiency [29].

absorption due to trapping of the light and barricading of the light's reflection. They recorded the maximum thermal efficiency of approximately $69.4 \%$ with a carbon-coated absorber plate which was $13 \%$ higher than that with the black-painted absorber plate. Figure 2 shows the obtained results for the abovementioned three coating materials.

Meena et al. [44] investigated the effect of absorber plate thickness on the collector's efficiency. They defined a parameter named the collector's efficiency factor, which increases by increasing the absorber plate thickness (Figure 3 ).

Kundu and Lee [31] conducted an analytical analysis by solving both Fourier and non-Fourier heat conduction equations in the absorber plates. To solve the parabolic and hyperbolic equations, a repetitive heat transfer module was applied. They used two types of boundary conditions, including isothermal and convective boundary conditions. At low Fourier number and high Vernotte number, different temperature distributions are obtained using the Fourier and 


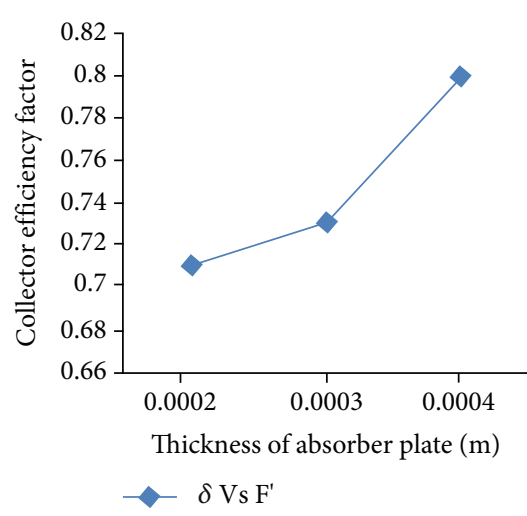

(a)

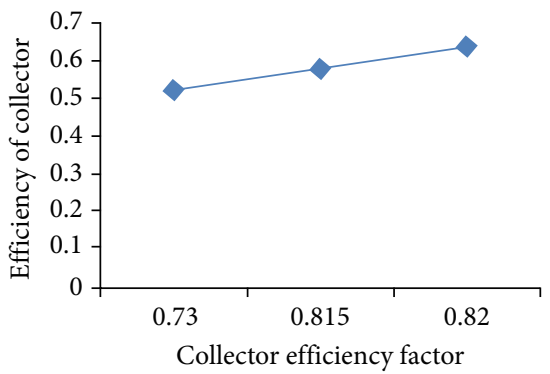

(b)

Figure 3: (a) Effect of absorber plate thickness on the collector efficiency factor. (b) Effect the of collector efficiency factor on collector efficiency [44].

non-Fourier models. They concluded that this deviation in temperature distribution is due to the increased incident of solar flux.

2.2. Riser Pipe. A riser pipe which is attached to the back of a flat plate, carries the working fluid, and transfers the received energy to it. Applying a material with higher conductivity coefficient for the riser pipe, higher working fluid temperature could be obtained.

Farhana et al. [36] simulated a flow of nanofluid in the header and riser to study the effect of the tube quantity and the diameter on the internal energy. They modeled a three-dimensional viscous laminar flow in the tubes. Their applied nanofluid was composed of $60 \%$ water and $40 \%$ ethylene glycol as a base fluid. They changed both header and riser tube diameters and the number of riser tubes. They found that the internal energy is not affected by the diameter and number of tubes and only depends on the physical properties of the nanofluid. Moreover, their results showed that some attention should be considered to design the header and riser tubes for fluids flowing through them.

Zhang et al. [37] numerically investigated a threedimensional heat pipe applying the finite volume method. They modeled a two-phase closed thermosyphon considering the thermal resistance networks. They studied the effect of evaporation length, inclination angle, heat pipe diameter, and absorber plate thickness on the thermosyphon thermal performance (Figure 4). They concluded that the heat pipe diameter of $12 \mathrm{~mm}$ results in the highest efficiency, increasing the evaporator length and absorber plate thickness increases the heat transfer, and the appropriate inclination angle is between $30^{\circ}$ and $45^{\circ}$ towards the south.

Deng et al. [39] investigated the thermal performance of the microchannel heat pipe array (MHPA-FPC) applied in a flat plate collector. They found that the stable time of the surface temperature along the MHPA is $2 \mathrm{~min}$. Their results showed that the excellent isothermal ability and quick thermal response speed of MHPA are due to the lowtemperature difference between the evaporator and condenser sections $\left(1^{\circ} \mathrm{C}\right)$. Maximum efficiency of $80 \%$ is obtained, which is $11.4 \%$ higher than the Chinese national standard. They compared their results with several samples and showed that the obtained efficiency is $25 \%$ higher than the average level of samples (Figure 5).

2.3. Glass Cover. The glass cover permits the solar beams to reach the flat plate and also prevents wasting of the unabsorbed and reflected energy as much as possible. As much as a highly transparent and less absorbing material is used in a glass cover, the highest collector efficiency could be obtained.

Morad et al. [14] investigated the thermal performance of the double-slope solar still considering the internal and external heat transfers. They studied both passive and active solar stills and measured the temperatures of the water, ambient, and internal and external glass cover surfaces for both solar stills. Three parameters, including basin brine depth, glass cover thickness, and glass cover cooling, were considered to investigate the performance, recorded temperatures, thermal efficiency, and productivity of the solar stills. Their results showed that the productivity and thermal efficiency of the active solar still $\left(10.06 \mathrm{~L} / \mathrm{m}^{2}\right.$.day and $80.6 \%$, respectively) are higher than those of the passive solar still $\left(7.8 \mathrm{~L} / \mathrm{m}^{2}\right.$.day and $\left.57.1 \%\right)$ (Figure 6).

Kumar and Mullick [26] proposed an empirical relation for glass cover temperature of a single-glazed flat plate collector. They proposed a relation only for the range of the angle of the tilt between 60 and $90^{\circ}$. They used the glass cover temperature obtained from their empirical relation to compute the upside loss coefficient of the collector. Moreover, the analytical equation was solved to estimate the upside heat loss coefficient. Their results showed that the maximum absolute temperature estimation error is in the range of $2 \%$ compared with the numerical solution of the heat balance equations.

Khoukhi and Maruyama [27] presented a rigorous theoretical approach to study the glass cover as absorbing-emitting media. The glass material was considered as a nongray plane-parallel medium exposed to solar and thermal irradiations in 1-D.

To calculate the solar and thermal radiation transfer of the glass cover, its optical constants proposed by Rubin were 

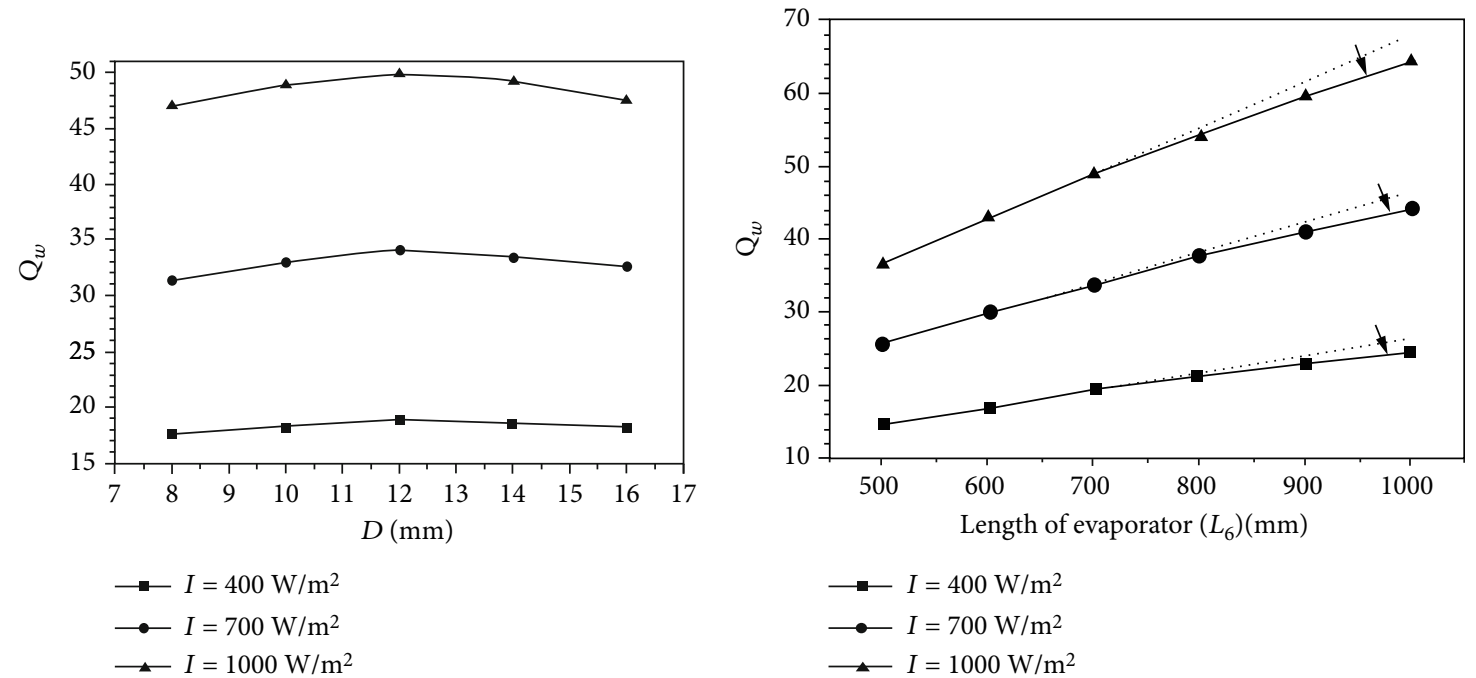

(a)
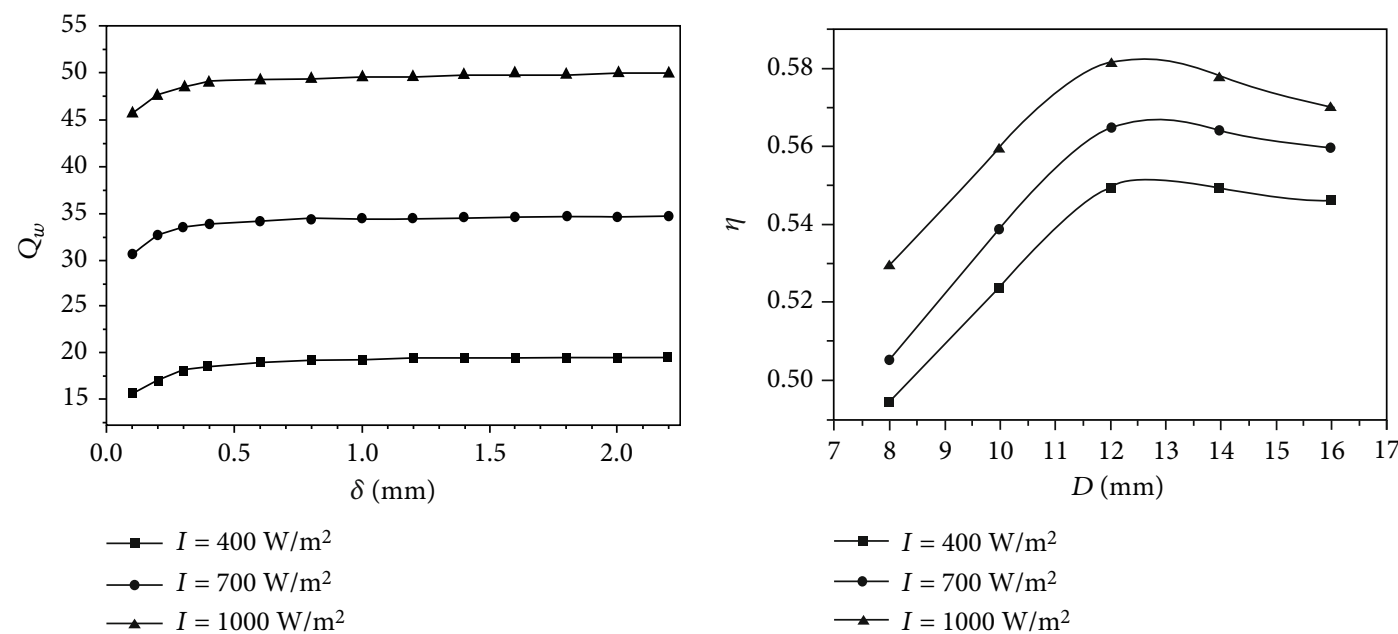

(c)

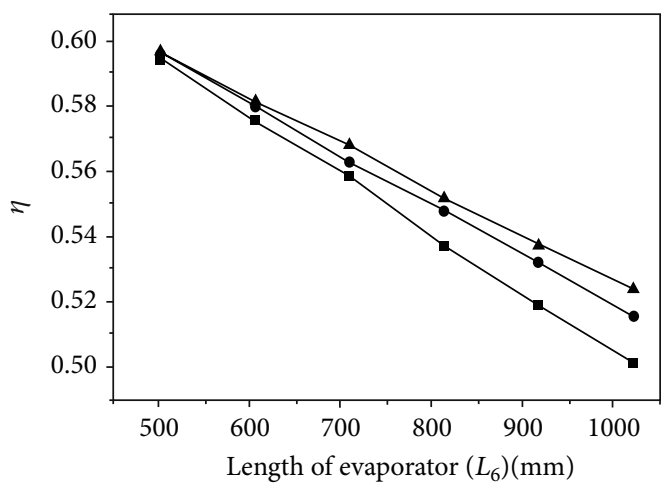

(d)

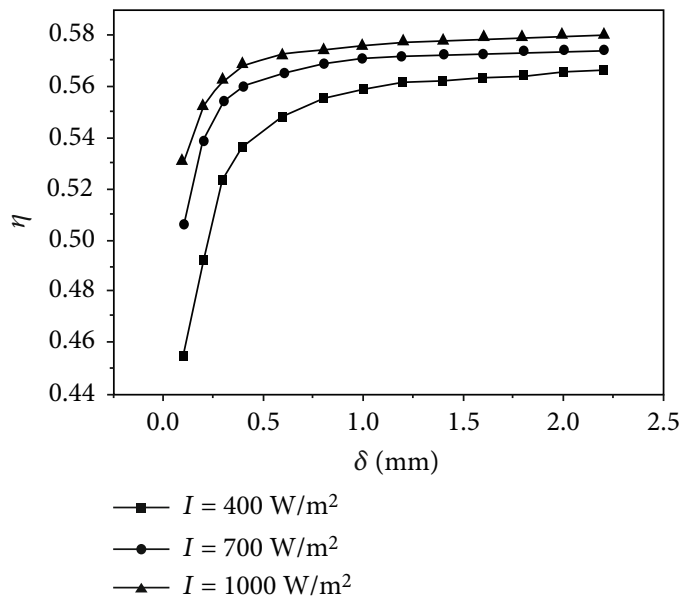

(f)

FIGURE 4: Effect of the heat pipe diameter, evaporation length, and collector plate thickness on the heat transfer and efficiency [37].

used, which were 160 constants in the real and imaginary parts. They found that the profile of the efficiency curve is more or less a straight line, when the convection heat trans- fer is the dominant heat transfer mode in comparison with the radiation one. It was demonstrated that the wind speed has a great effect on the glass cover mean temperature and 

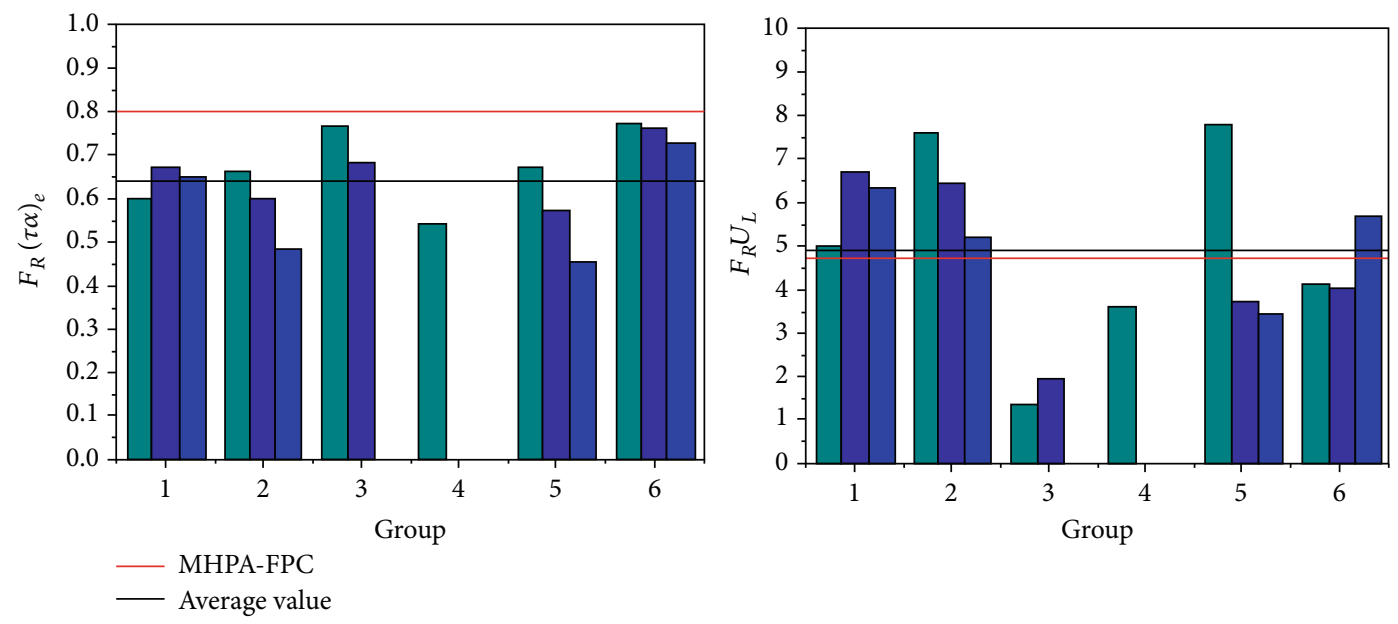

Figure 5: Comparison between MHPA-FPC and samples [39].

its effect could be enhanced by increasing the mean absorber temperature.

\subsection{Frame and Insulation. Collector's frame and insulation} are applied to increase its efficiency by preventing the escape of energy. Chen et al. [41] investigated the effect of the aluminum foam porous structure filled with paraffin on the energy storage process and heat transfer of a solar flat plate collector. Darcy's law with the Brinkman-Forchheimer's extension was used to model the liquid paraffin motion and applied the two-temperature model to model the heat transfer between the metal foams and paraffin. Their results showed that the assumption of the local thermal equilibrium between the metal foams and paraffin is not completely predicting the heat transfer behavior; the two-temperature model shows better results of the phase change heat transfer process. They concluded that the heat transfer performance improves, using the aluminum foams filled with paraffin.

Zhou et al. [42] investigated the performance of polymethyl methacrylate sheet integrated into a flat plate collector using a 3-D simulation model. They decided to find an effective solution for the cold environments, since the collectors have high heat loss and low efficiency at those environments. Moreover, they conducted an experiment to verify the obtained numerical data. The thickness and location of the polymethyl methacrylate sheets were studied in a steady-state condition. Their results showed that the best thickness of the polymethyl methacrylate sheet is $1 \mathrm{~mm}$ and the collector efficiency improves by $11.3 \%$ using $0.1 \mathrm{~m}^{2}$ $\mathrm{C} / \mathrm{W}$ of the reduced temperature at an ambient temperature of $-20^{\circ} \mathrm{C}$ (Figure 7 ).

Kessentini et al. [43] numerically and experimentally investigated the application of plastic transparent insulation materials and a low-cost overheating protection system in a flat plate collector. They designed a ventilation channel to protect the collector from stagnation conditions and also kept the collector's performance in normal condition. Their numerical solution was based on the resolution of the different components of the solar collector employing a modular object-oriented platform. They studied different configura- tions of the flat plate collectors, transparent insulation materials, and ventilation channels through virtual prototyping to optimize and do the parametric study. Their results showed an optimized design which works at an operating temperature of $100^{\circ} \mathrm{C}$, applicable in industries which need heat transfer at low to medium temperature levels.

Moreover, there are a few methods to calculate the collector efficiency, including static modeling [45-47], dynamic modeling [48-50], energy analysis [51-53], and exergy analysis [54-56].

\section{A Simple Solar Still}

Water for all of the creatures is a vital element as 70 percent of our planet is covered by it, while only 3 percent of it is potable and the rest is nonpotable (contaminated, impure, salty, or brackish) [57]. A solar still system is a cheap procedure to produce potable water applying solar energy. Therefore, it is a good alternative to other energies. Among different desalination methods, the solar still system is the simple one. A schematic of a solar still system is shown in Figure 8, which consists of the basin, transparent cover, and distillate trough.

3.1. Transparent Cover. The transparent cover performs three functions, i.e.; permits the sunlight to enter the solar still and evaporate saline water, keeps the wind away from the evaporating water to decrease the heat losses, and acts as a condenser which changes the water vapor to liquid. The cover's slope must be high to conduct the droplets (condensed water vapor) toward the trough without falling into the saline water. The cover is preferred to be made of glass due to its high transparency, rigidity, and low cost. Although plastics are easy to handle, inexpensive, and lightweight, they will be discolored and deteriorated due to the sunlight (ultraviolet radiation).

3.2. Basin. A basin is used to keep the saline water for distillation. To increase the performance, it is insulated to reduce the heat loss into the surroundings. To enhance the 


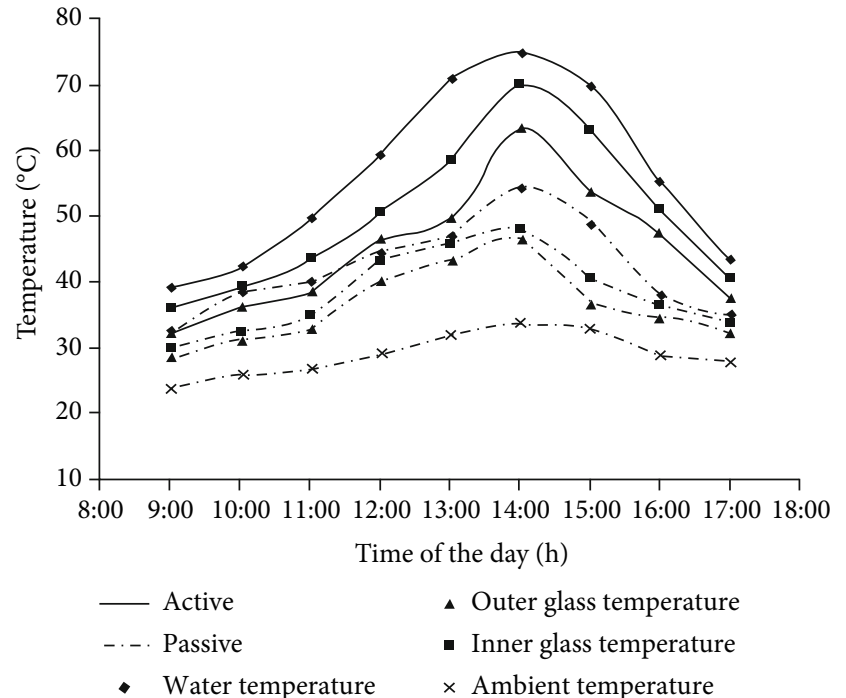

(a)

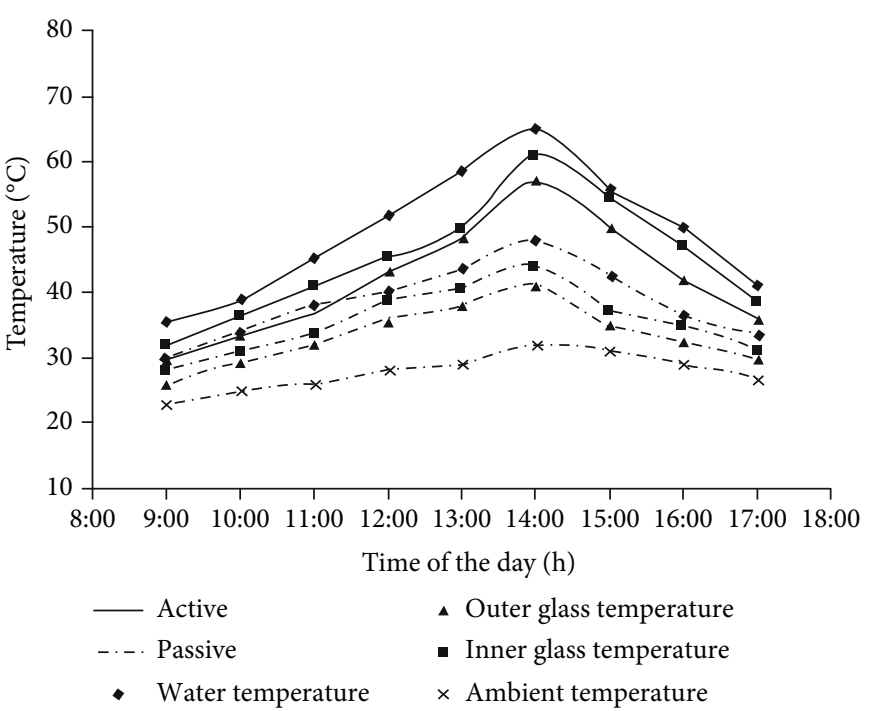

(b)

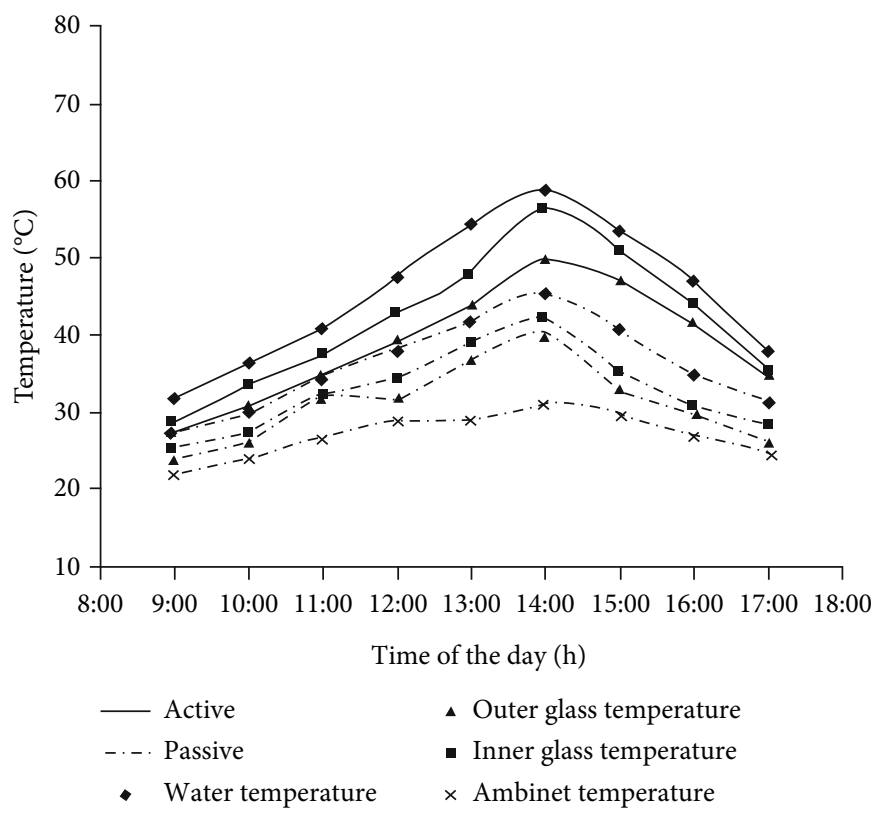

(c)

Figure 6: Glass cover thickness effect on the temperature measurement, (a) $3 \mathrm{~mm}$ thickness, (b) $4 \mathrm{~mm}$ thickness, and (c) $5 \mathrm{~mm}$ thickness [14].

absorptivity, it is usually lined with a black sheet or is painted black. After a few moments, the saline water becomes concentrated; therefore, the basin floor has to be inclined around one degree to drain effortlessly. To have a long life, basin materials have to be resistant to corrosion of saline water, and further, to be highly accessible, they have to be cheap, durable, and locally available. Some materials which could be used, including plastic, are wood impregnated with a resin, aluminum, iron painted to resist corrosion, or concrete.

3.3. Distillation Trough. Distillation trough is located at the lower-end edge of the cover to collect the droplets (distillation water droplets).
Solar stills can be called a small-scale hydrological cycle, whose efficiency depends on some meteorological limitations including ambient temperature, solar radiation, wind speed, and sky clearness. Moreover, their productivity depends on some operating factors involving its design, cover slope, shape material, brine depth, thermal insulation, vapor leakage, and etc. There are different solar stills considering the type of applied materials, the arrangements for supply and discharge water, the method of supporting the transparent cover, and their geometries. Some configurations include a reflector, solar collector, and latent heat of condensation.

3.4. Energy Analysis. A significant part of the researches on the topic of solar energy considered the energy analysis, 


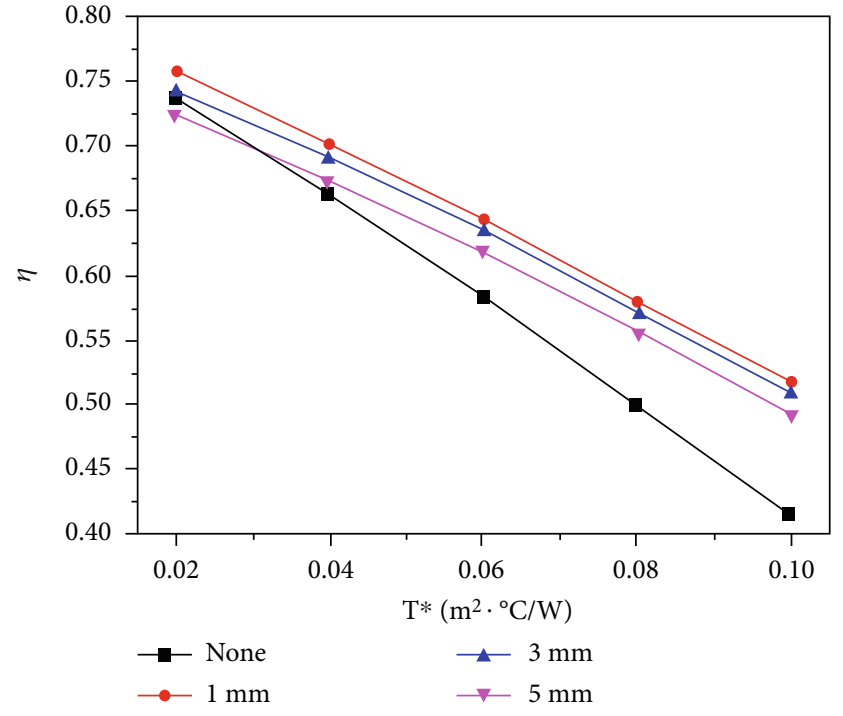

(a)

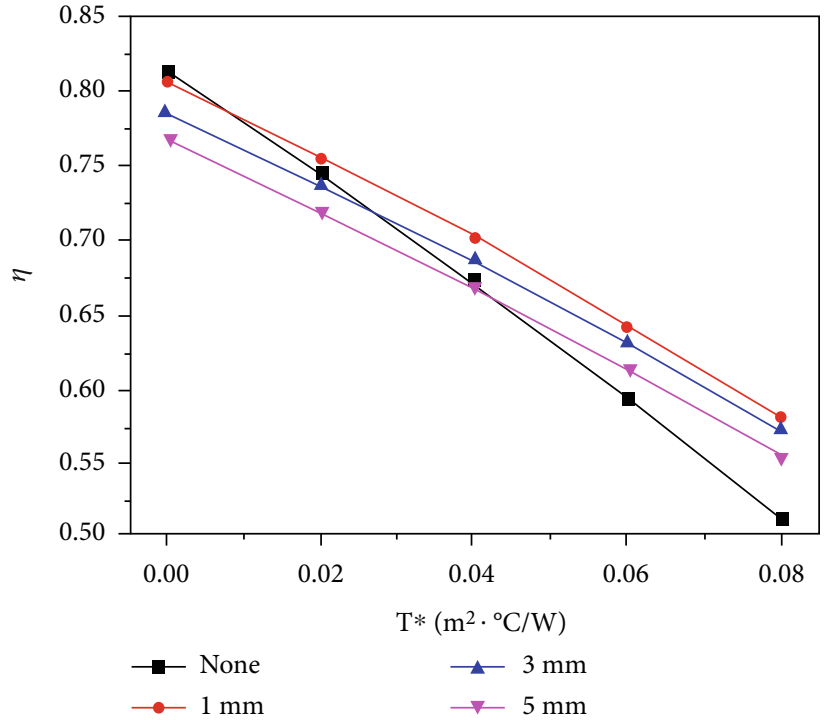

(b)

FIGURE 7: Effect of the thickness and environment on efficiency, (a) $-20^{\circ} \mathrm{C}$ and (b) $0^{\circ} \mathrm{C}$ [42].

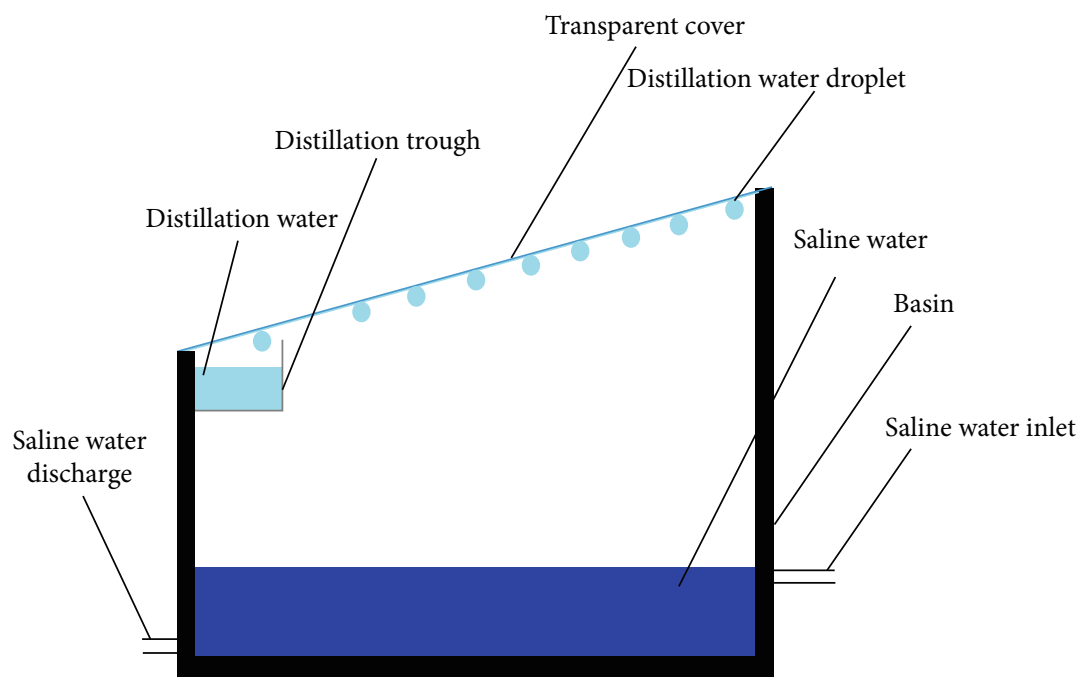

FIGURE 8: A schematic view of a simple solar still system.

concerning its performance. In fact, the energy analysis indicates that how much the system is successful and useful for the intended purpose. In solar stills, which their performance depends on the sky and surrounding conditions, the energy analysis is necessary. In this section, a summary of important researches which focused on the energy analysis of the solar still coupled into a flat plate collector is reviewed.

The solar still efficiency could be usually calculated using the following equation:

$$
\eta=\frac{\sum m h_{f g}}{\sum A I},
$$

in which $m, h_{f g}, I$, and $A$ are the productivity, latent heat, solar intensity, and surface area exposed to the solar intensity, respectively.
Rajaseenivasan et al. [58] studied two types of solar stills including a conventional solar still and a solar still coupled with a flat plate collector to preheat the saline water. In the second solar still, a basin area of $1 \mathrm{~m}^{2}$ and a horizontal flat plate collector arrangement were used, which involve six small compartments in the basin. They investigate separate compartments in the second solar still to decrease water's mass which increased the evaporation rate. In their experiments, different water depth, wick materials, and energystoring materials (jute cloth and black gravels) were applied to study the performance in both solar stills. The solar intensity, wind velocity, ambient temperature, yield, and temperatures at different parts were recorded from 9 AM to $6 \mathrm{PM}$. They indicated that the hourly efficiency of the flat plate collector coupled with a solar still is higher than that of the conventional one in the same condition due to the highheat transfer rate and, as a result, high evaporation rate. 


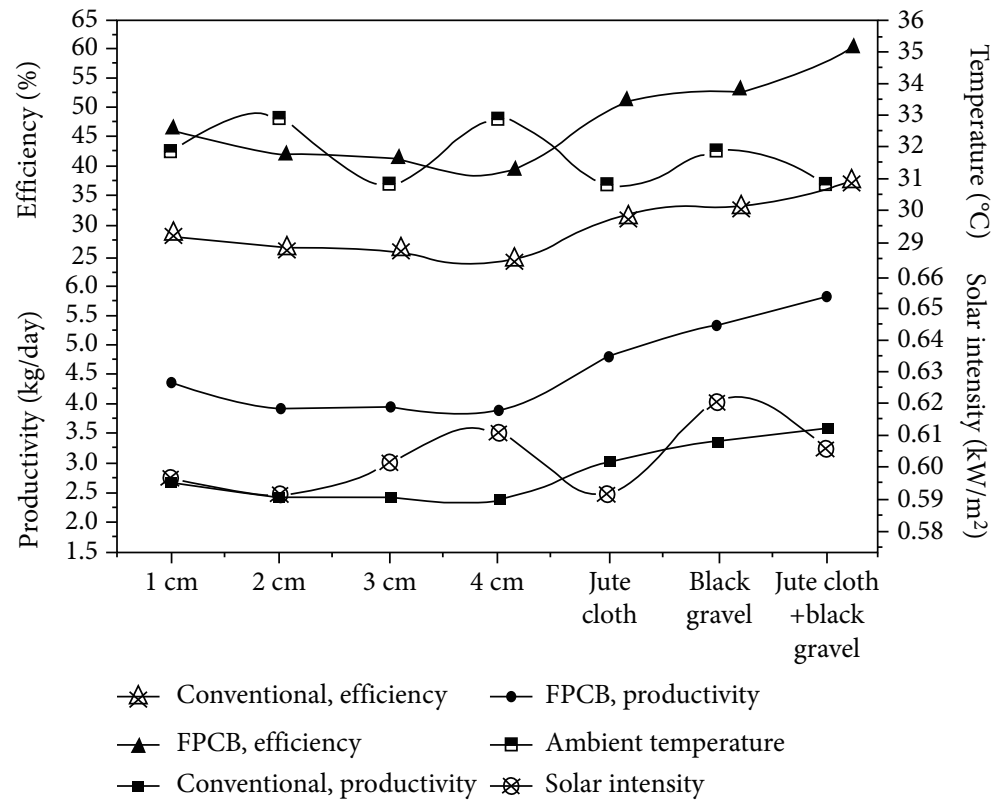

Figure 9: Effect of different parameters in the conventional solar still and the flat plate collector coupled with a solar still [58].

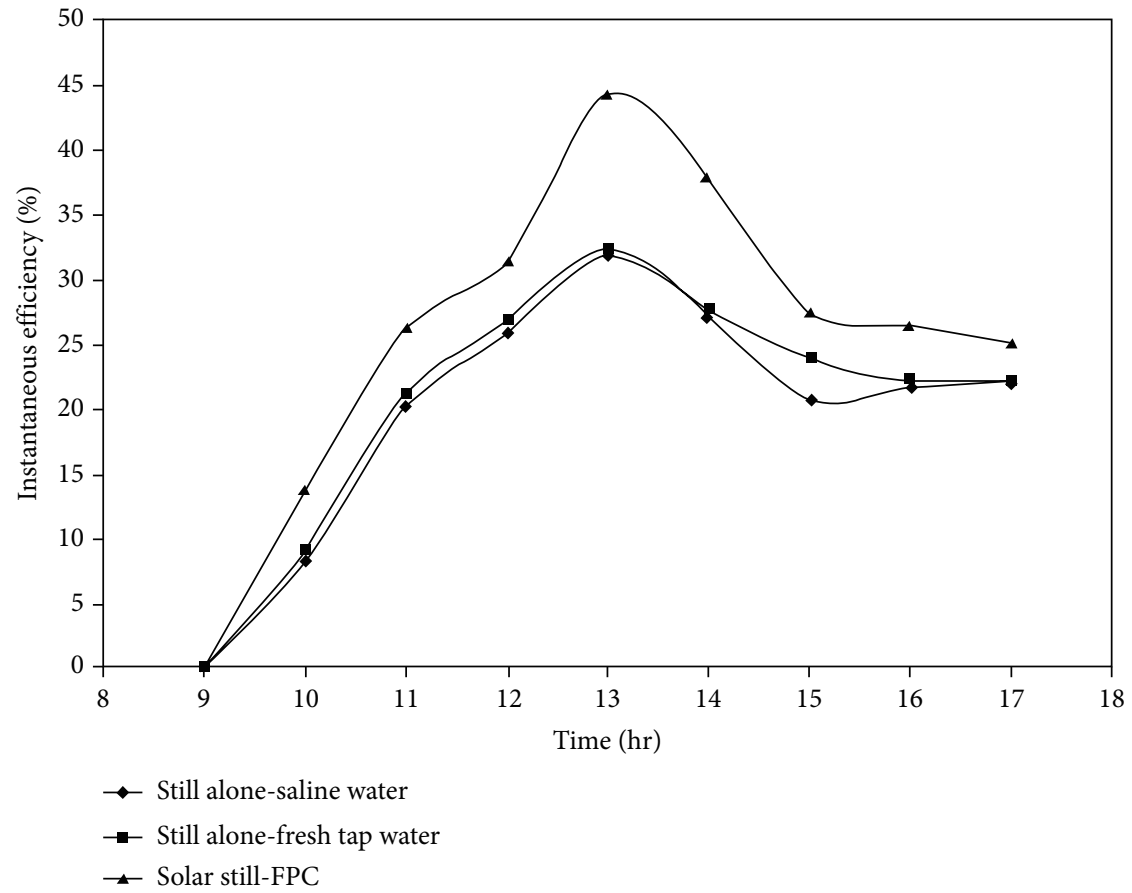

Figure 10: Comparing efficiency of the solar stills with freshwater, saline water, and the solar still coupled with a flat plate collector with freshwater [59].

Figure 9 shows their obtained efficiency, productivity, ambient temperature, and average solar intensity for the both stills. It should be noted that the maximum efficiency of the conventional still and the flat plate collector coupled with a still were $37 \%$ and $60 \%$, respectively.

Sheeba et al. [59] compared the performance of a conventional solar still with a solar still coupled with a flat plate collector, considering the efficiency improvement. They tested the performance of both solar stills with two types of water; fresh tap water and saline water. They used freshwater in the solar still coupled with flat plate collector to avoid effects of corrosion. The daily efficiency of the solar still coupled with a flat plate collector was 20.4 and $23.6 \%$ higher than the two conventional solar stills containing freshwater and saline water, respectively (Figure 10). Also, efficiency of the solar still with freshwater was $4 \%$ higher than efficiency of the solar still with saline water. 


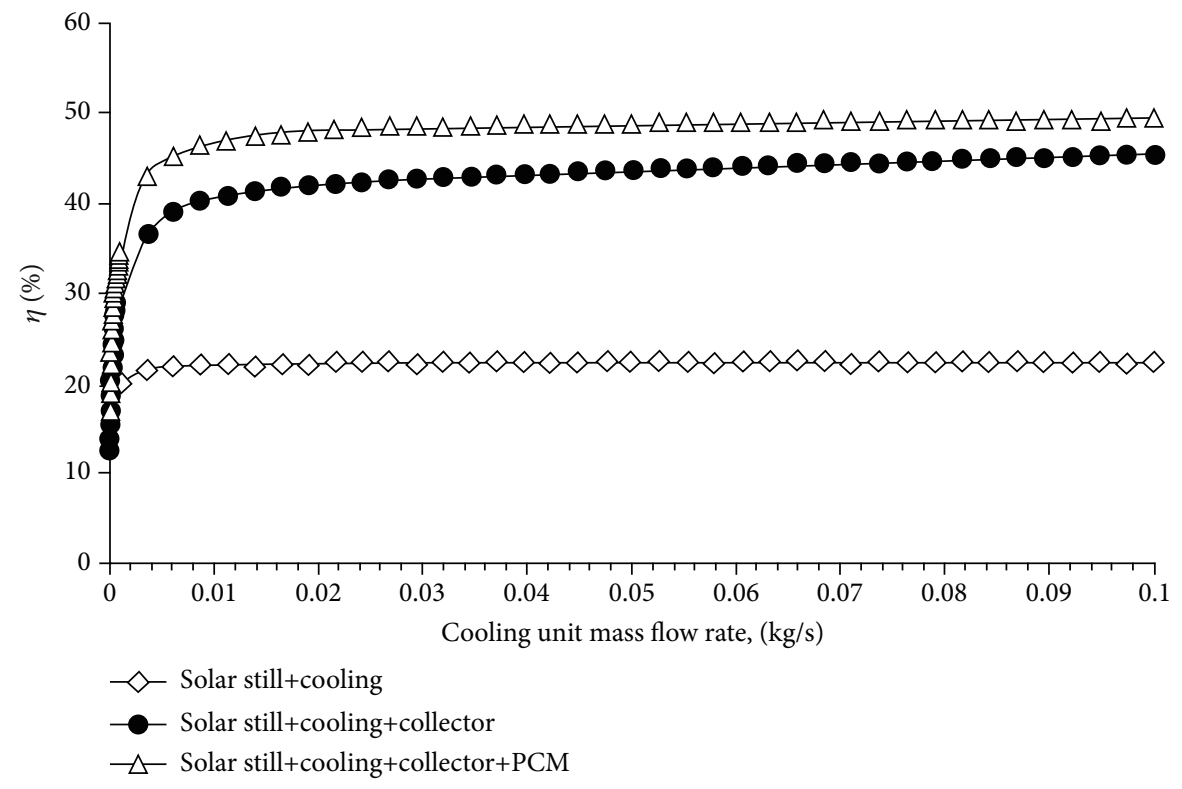

FIgURE 11: Cooling mass flow rate effect on the efficiency [15].

Khechekhouche et al. [60] investigated the effect of glass cover thickness on efficiency of a solar still considering three different glass thicknesses. They stated that the solar energy flows through the glass cover as heat; therefore, the higher glass cover's temperature, the lower solar still's productivity. Their results showed that the glass thickness of $3 \mathrm{~mm}$ yields better efficiency for the conventional solar still. The measured energy efficiency was $30.71,19.02$, and $11.44 \%$ for different cover thicknesses of 3,5, and $6 \mathrm{~mm}$, respectively. Also, the energy efficiencies with a cover thickness of $3 \mathrm{~mm}$ are $40.25 \%$ and $63.37 \%$ higher than those for the cover thicknesses of 5 and $6 \mathrm{~mm}$, respectively.

Badran et al. [61] coupled a flat plate collector to the solar still to study its productivity. They used a single-stage, basin-type solar still with a flat plate collector to investigate the amount of distilled water in different local conditions. Their experiments were carried out in different conditions including various solar intensities and temperatures in several days. They tested the solar still at several configurations involving a solar still coupled with a collector for the period of $24 \mathrm{~h}$, solar still coupled with a collector from 8 am to $5 \mathrm{pm}$, and solar still without a collector for $24 \mathrm{~h}$. The tap water and saline water were used as a feed. The daily energy efficiency of the solar still without the collector was $27 \%$, which showed a nearly $2.5 \%$ reduction for the solar still coupled with a collector.

Abu-Arabi et al. [15] theoretically studied the solar still performance at three phases: phase (1), solar still with glass cooling; phase (2), connecting solar still to a collector; and phase (3), using a phase change material in phase (2). They used three materials as the phase change material including paraffin wax, sodium thiosulfate pentahydrate, and sodium acetate trihydrate. They investigated the effects of the different groups of parameters on the solar still efficiency. The first group of parameters which is controllable includes the cooling water flowrate, PCM mass, and hot water circulation

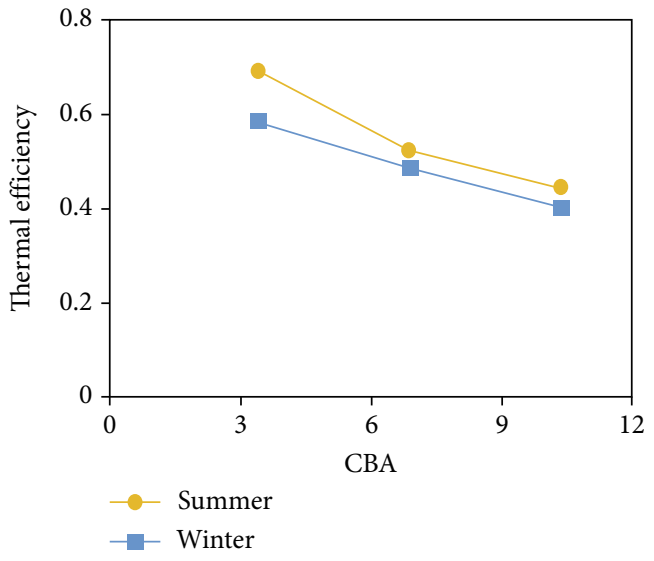

Figure 12: Effect of CBA on the thermal efficiency [62].

rate, and the second group of parameters which is uncontrollable includes wind speed, solar irradiation, and ambient temperature. Their results showed that the effect of increasing solar radiation from $200 \mathrm{~W} / \mathrm{m}^{2}$ to $700 \mathrm{~W} / \mathrm{m}^{2}$ leads to efficiency enhancement from $20.5 \%$ to $23.1 \%, 37.2 \%$ to $42.7 \%$, and $46.5 \%$ to $50.1 \%$ for the three previously mentioned phases, respectively. Also, they investigated the effect of ambient temperature on efficiency, which leads to its increment from 48.2 to $49.3 \%, 40.9$ to $41.1 \%$, and 22.2 to $22.3 \%$ for the so-called phases, respectively. Increasing the wind speed from 0 to $20 \mathrm{~m} / \mathrm{s}$ caused the efficiency to enhance from 48.6 to $49.2 \%$ for phase (3), while it was $22.4 \%$ and $41.1 \%$ for phases (1) and (2), respectively. The affected efficiency from the different cooling water flow rate was from 22.1 to $22.3 \%$, 40.8 to $45.5 \%$, and 46.9 to $49.3 \%$ for configurations of the solar still with glass cooling, collector connecting, and phase change materials, respectively (Figure 11).

Feilizadeh et al. [62] investigated a multistage solar still performance at different ratios of the collector to basin area 


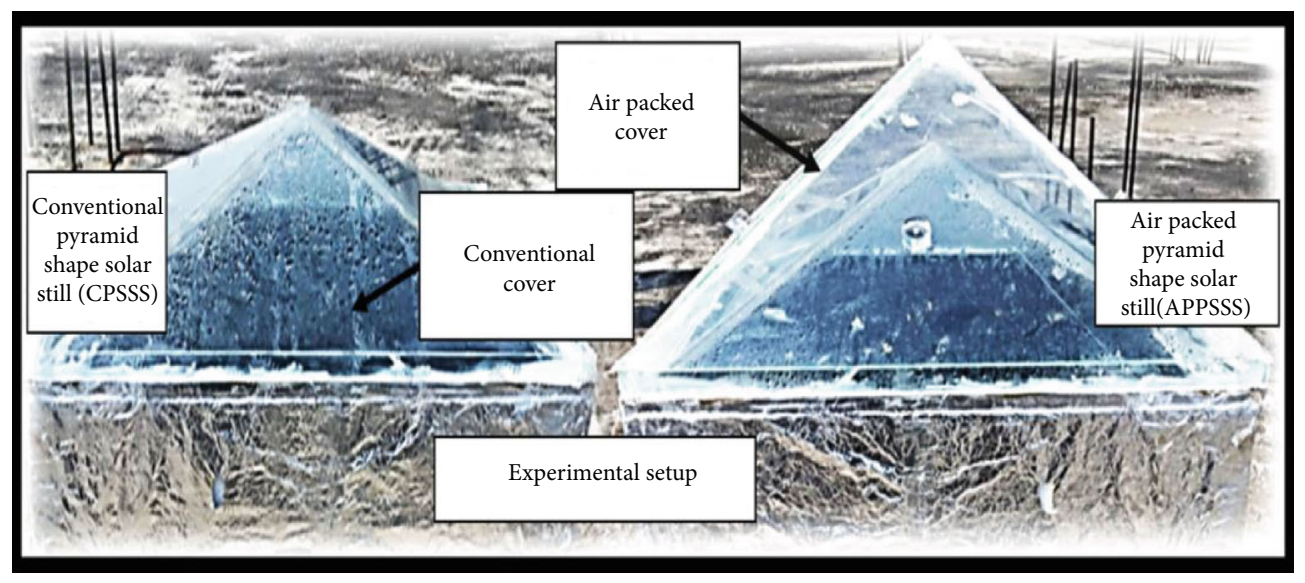

FIGURE 13: Conventional pyramid and air-packed pyramid-shaped solar still [63].

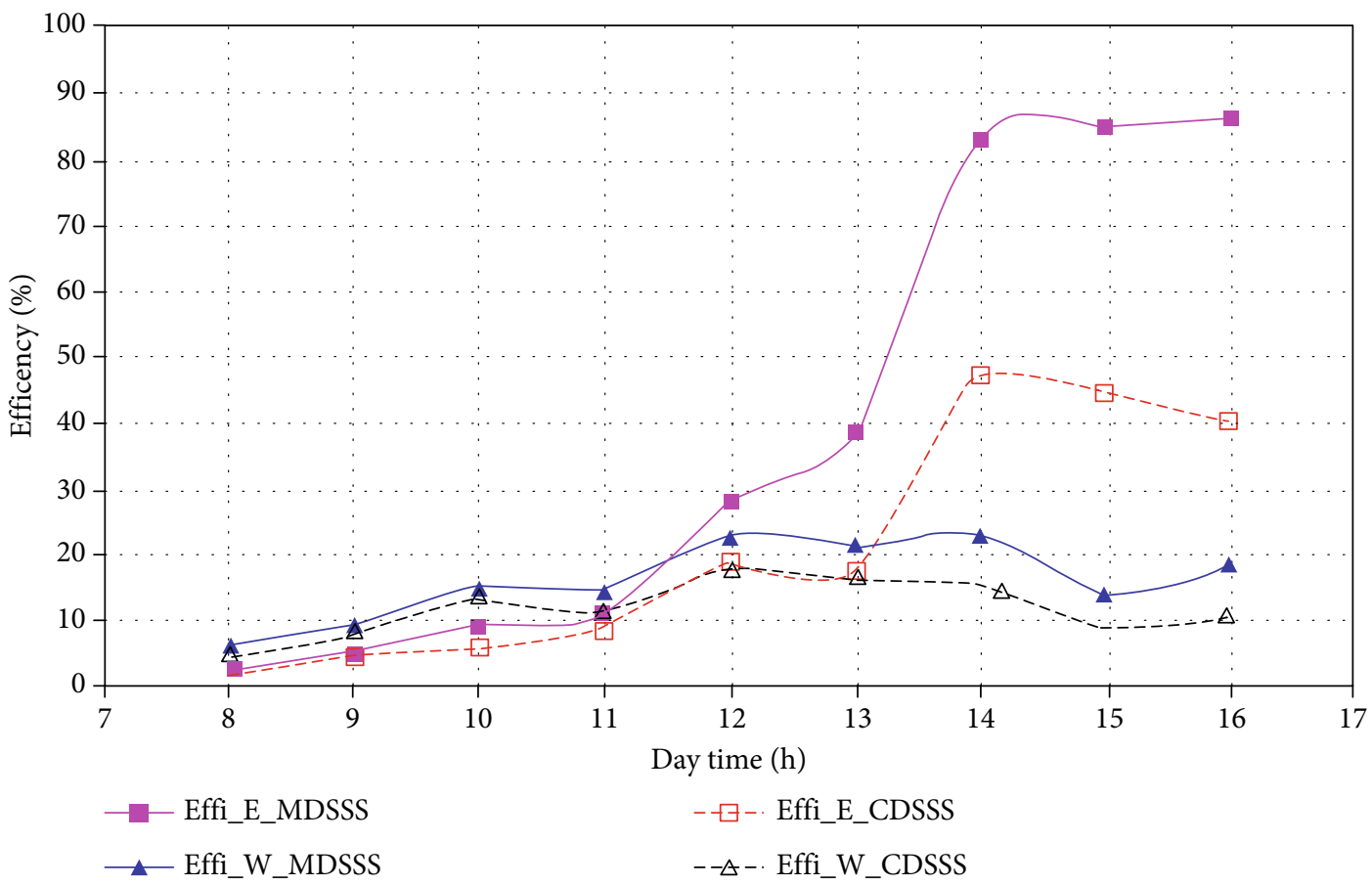

FIgURE 14: Effect of orientation and preheating on hourly efficiency [64].

(CBA). The solar still was coupled with one, two, and three flat plate collectors. They indicated that higher CBA leads to lower thermal efficiency of the solar still (Figure 12). They explained that the temperature of the still and the total heat losses increase by increasing the input energy. Moreover, the evaporation area of the basin chamber remains constant which based on the derived equations, the evaporation ratio does not change by increasing the collector area.

Kumar et al. [63] are interested to study the pyramid shape of the solar still, which receives the solar radiation from four directions. They experimentally investigated the effect of the air-packed cover in the conventional pyramid solar still, located on its top. The air-packed layer acted as an insulation layer to protect against losing the heating energy from the glass cover. They observed that the conven- tional pyramid solar still had a higher performance at $1 \mathrm{PM}$ to $6 \mathrm{PM}$ while the performance of the air-packed pyramid solar still was less. Thermal efficiency of the air-packed pyramid solar still increased to $44.33 \%$ compared with the conventional double-glass solar still (Figure 13).

Al-Molhem and Eltawil [64] studied the effect of the coupling solar collector to the solar still, using floatable black wicks in the solar still and modifying it to a double-slope solar still. They used a black hose to form a coil as the collector to preheat the saline water. The floatable black wicks were applied to enhance the evaporation surface area and introduce a locally absorb insulation at the evaporation surface. They used two orientations in the longitudinal axis, north-south and east-west, and the measured amount of distilled water from each orientation (Figure 14). 


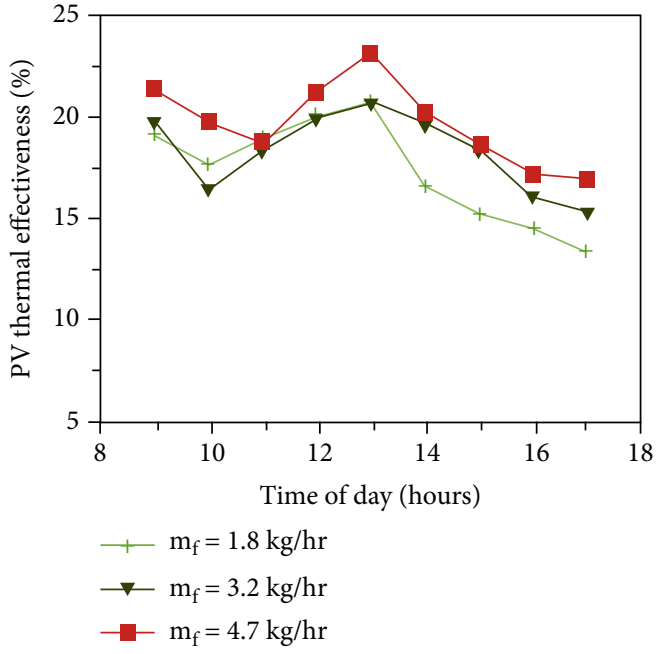

FIGURE 15: Effect of the water mass flow rate on the PV thermal efficiency during a day [66].

MohanRai et al. [65] investigated the solar still performance at different configurations of having no flat plate, a single flat plate, and a series of flat plates. They checked the amount of distilled water and the overall efficiency of desalination units. The solar still operation was tested from $10 \mathrm{AM}$ to $5 \mathrm{PM}$. They observed that the conventional solar still has an efficiency of $23 \%$, while the solar still coupled with a single collector has an efficiency of $15.9 \%$ and the solar still coupled with a series of the collectors has the efficiency of $13.25 \%$.

Manokar et al. [66] studied the freshwater production from an active inclined solar panel basin solar still. They showed that the daily thermal efficiency of the solar still unit at water mass flow rates of $1.8,3.2$, and $4.7 \mathrm{~kg} / \mathrm{h}$ is 43.71 , 38.27, and 29.62\%, respectively. Moreover, their results showed that their daily PV panel powers at the aforementioned water mass flow rates are about 47.71, 49.84, and 53.83 watts, while the electrical efficiencies are about 7.2, 7.6 , and $8.1 \%$, respectively. Besides, their thermal efficiencies are about $17.3,18.3$, and $19.7 \%$ and their overall thermal efficiencies are about $61.39,57.44$, and $51.37 \%$, respectively. Therefore, increasing the mass flow rate leads to the reduction of productivity, thermal efficiency, and overall thermal efficiency, while the PV panel power, thermal, and electrical efficiencies are increased (Figure 15).

Eltawil and Omara [67] worked on a solar still integrated with a flat plate collector, spraying unit, perforated tubes, solar air collector, and external condenser, in which the obtained results are compared with those of the conventional solar still. They used photovoltaics (PV) to power the solar still and measure its productivity at different conditions. The solar still integrated with the air collector and condenser shows lower efficiency of $21 \%$ in comparison to the conventional solar still. Using a condenser, hot air, and hot water spray caused higher daily efficiency of $29 \%$.

Narayana and Raju [68] studied the effect of a flat plate collector on the internal heat transfer coefficient, amount of distilled water, and efficiency of a solar still. They used a

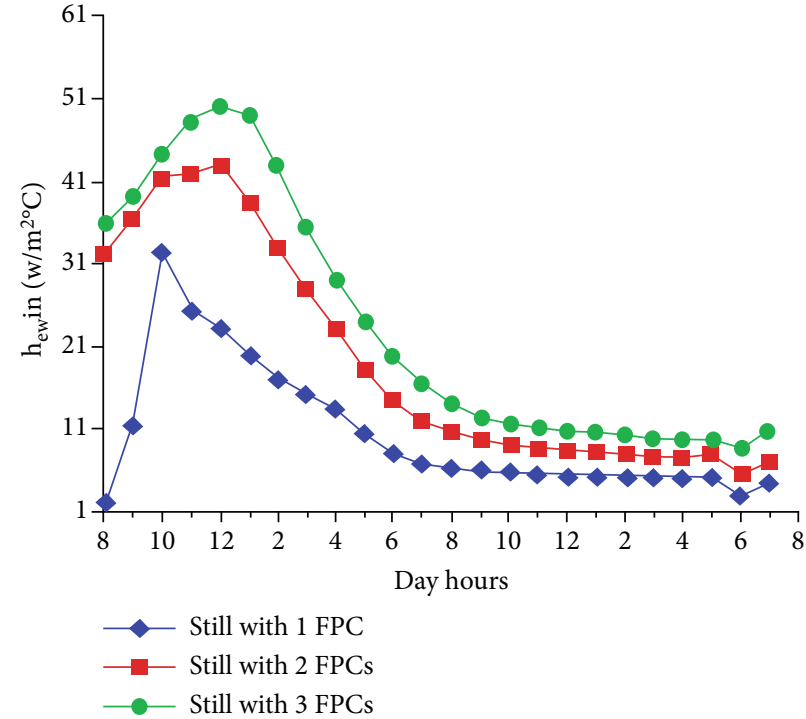

FIGURE 16: Effects of the number of the flat plate collector on the evaporative heat transfer coefficient [68].

basin area of $1 \mathrm{~m}^{2}$ with a 30 -degree inclination and a flat plate collector of $2 \mathrm{~m} 2$ with a 50-degree inclination (Figure 16). They found that the heat transfer coefficient depends on the collector size. The efficiencies of the solar still coupled with one flat plate collector, two flat plate collectors, and three flat plate collectors are $6.82 \%, 6.93 \%$, and $5.79 \%$, respectively. The solar still coupled with two flat plate collectors showed higher efficiency, in comparison to the other applied solar stills. In comparison to the solar still coupled with one flat plate collector, coupling the solar still with two and three flat plate collectors results in the distillate efficiency being $0.11 \%$ higher and $1.03 \%$ lower, respectively.

Menon [69] studied the performance of the solar still coupled with a flat plate collector, considering some parameters including solar radiation, water depth, and still direction. They investigated both solar still performance and efficiency enhancement. The obtained results showed a $12 \%$ efficiency enhancement. That is, the average efficiencies in five and nine days were $44.62 \%$ and $56.42 \%$, respectively.

Figure 17 and Table 1 indicate the efficiency of different reviewed solar still configurations including a conventional one, one with flat plate collector, and one with other applied components. The average efficiency is $30.9 \%$ and higher than many studied solar stills' efficiency. The obtained efficiencies which are higher than the average may be due to better environmental conditions, better quality of materials, insulations, components, some overestimation, incorrect calculations, etc. It should be noted that the efficiency of reference [58] which relates to a solar still coupled with flat plate collectors has the maximum efficiency of $60 \%$. In that research, six small compartments are applied in the basin to increase the evaporation rate. The efficiency of reference [68], in which three flat plate collectors are applied, has the minimum efficiency of $5.69 \%$. They used one, two, and three flat plate collectors to study their effects on some parameters, including the 


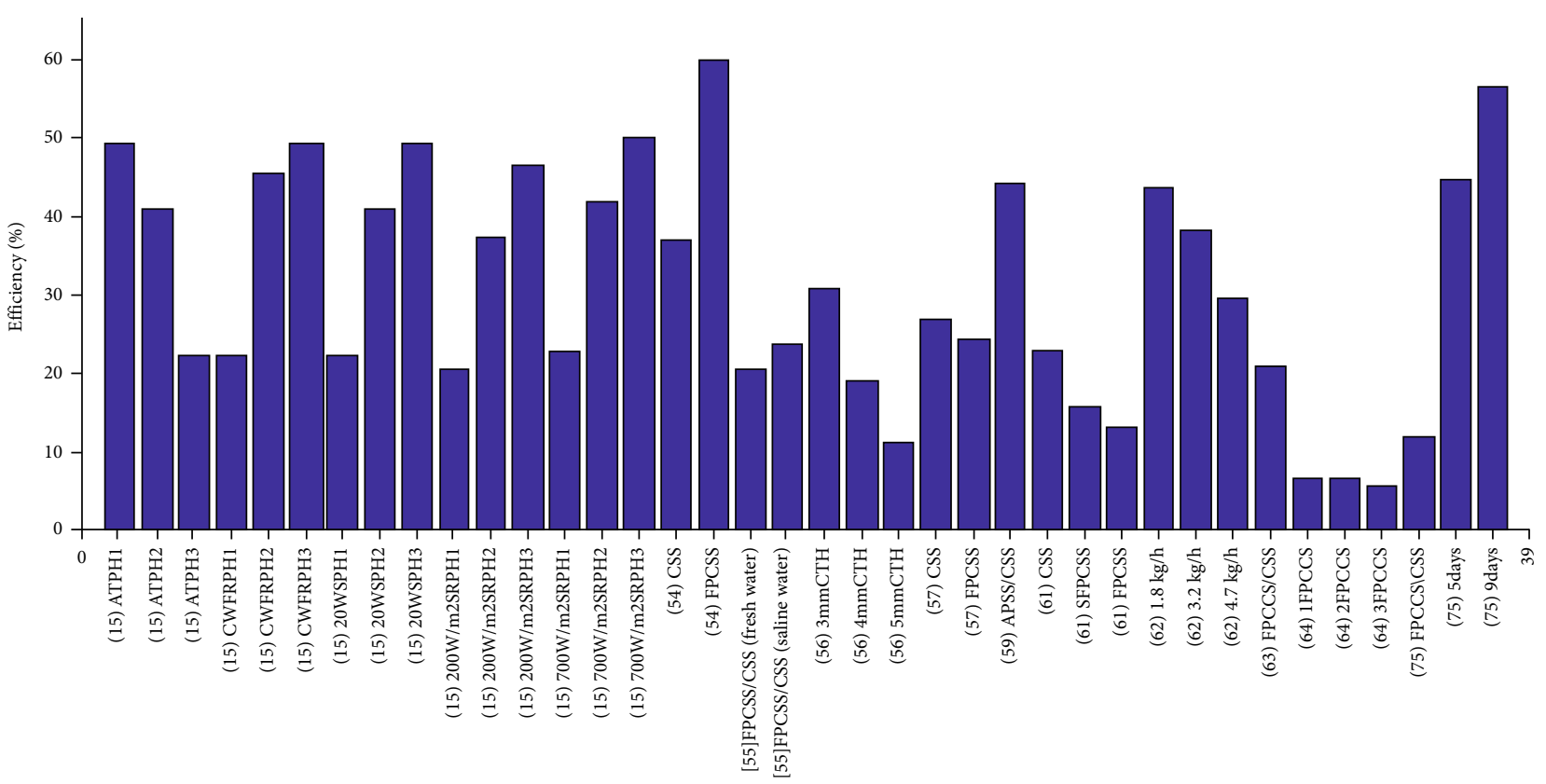

FIgURE 17: Efficiency of different types of solar stills.

internal heat transfer coefficient, amount of distilled water, and efficiency, applying a basin area of $1 \mathrm{~m}^{2}$ and 30-degree inclination and a flat plate collector area of $2 \mathrm{~m}^{2}$ and $50-$ degree inclination.

3.5. Exergy Analysis. A few researches has been conducted exergy analysis of the solar still efficiency. In this part, the exergy efficiency of the solar still coupled with a flat plate collector is presented and its significant outcomes are investigated.

Khechekhouche et al. [60] calculated the exergy efficiency of a conventional solar still at different cover thicknesses of 3,5 , and $6 \mathrm{~mm}$, which were 2.46, 1.38, and $0.84 \%$, respectively. They stated that the exergy efficiencies of the $3 \mathrm{~mm}$ cover thickness, in comparison to the cover thicknesses of 5 and $6 \mathrm{~mm}$, are $44.01 \%$ and $65.81 \%$ higher, respectively.

Manokar et al. [66] found that for a solar still unit at mass flow rates of $1.8,3.2$, and $4.7 \mathrm{~kg} / \mathrm{h}$, the exergy efficiencies are $18.32,20.23$, and $22.39 \%$ and the overall exergy efficiencies are 26.52, 27.14, and 27.40, respectively. Therefore, increasing the mass flow rate reduces both exergy and overall exergy of the solar still, while the exergy and overall exergy efficiencies of the PV panel power are increased (Figures 18 and 19).

3.6. Economic Analysis. The desalination process using the fossil fuels is an expensive method that had been applied since World War II due to the high demand for healthy water. However, desalination costs have decreased the trend by using new and cheaper technologies. Using solar desalination has the advantages of zero fossil fuel costs, no pollution, and stopping global warming, while having disadvantages of not needing a large space and being timeconsuming. Therefore, using renewable sources (e.g., solar radiation) is necessary to study the possibility of water desalination. In this part, some investigations of different types and configurations of the solar stills are reviewed to evaluate the water desalination costs.

Rajaseenivasan et al. [58] showed that the net cost of distilled water obtained from a solar still coupled with a flat plate collector is cheaper than that of the conventional solar still (without a flat plate collector). However, the initial cost of the conventional solar still is $15 \%$ less than that of the solar still coupled with flat plate collector. They investigated the application of wick and energystoring materials in the basin and reported that they cost $\$ 0.0362$ and $\$ 0.0276 / \mathrm{kg} / \mathrm{m}^{2}$ for the conventional solar still and the solar still coupled with a flat plate collector, respectively.

Sethi and Dwivedi [70] developed a version of a solar still coupled with a flat plate collector for small-scale applications. They estimated the cost of distilled water by analyzing the life cost of the previously mentioned solar still. Moreover, the payback periods of distilled water were evaluated for different conditions, namely, the produced cost and the market price rate. The minimum and maximum costs of distilled water in conditions that the lifetime of the solar still was considered to be 50 and 30 years were $\$ 0.0079$ and $\$ 0.030$ per $\mathrm{kg}$, respectively, and the interest rate was $4 \%$ and $16 \%$, respectively. The payback time of 1.23 and 26.58 years was the minimum and maximum time at a selling price of $\$ 0.13$ and a selling price equal to the production price, respectively.

Kerfah et al. [71] designed a modular solar still to numerically perform a thermal-economic analysis and investigate the effect of the collector and condensation chamber area on the productivity and the cost of distilled water. They found that increasing the collector area reduces the distilled water cost, while the amount of freshwater 
TABLE 1: Solar still efficiency of studied references.

\begin{tabular}{|c|c|}
\hline Reference & Efficiency (percent) \\
\hline [15] ATPH1 & 49.3 \\
\hline [15] АТРН2 & 41.1 \\
\hline [15] АТРН3 & 22.3 \\
\hline [15] CWFRPH1 & 22.3 \\
\hline [15] CWFRPH2 & 45.5 \\
\hline [15] CWFRPH3 & 49.3 \\
\hline [15] $20 \mathrm{~W}$ SPH1 & 22.4 \\
\hline [15] $20 \mathrm{~W} \mathrm{SPH} 2$ & 41.1 \\
\hline [15] $20 \mathrm{~W}$ SPH3 & 49.2 \\
\hline [15] $200 \mathrm{~W} / \mathrm{m}^{2} \mathrm{SRPH} 1$ & 20.5 \\
\hline [15] $200 \mathrm{~W} / \mathrm{m}^{2} \mathrm{SRPH} 2$ & 37.2 \\
\hline [15] $200 \mathrm{~W} / \mathrm{m}^{2} \mathrm{SRPH} 3$ & 46.5 \\
\hline [15] $700 \mathrm{~W} / \mathrm{m}^{2} \mathrm{SRPH} 1$ & 23.1 \\
\hline [15] $200 \mathrm{~W} / \mathrm{m}^{2} \mathrm{SRPH} 2$ & 42.1 \\
\hline [15] $700 \mathrm{~W} / \mathrm{m}^{2} \mathrm{SRPH} 3$ & 50.1 \\
\hline [54] CSS & 37 \\
\hline [54] FPCSS & 60 \\
\hline [55] FPCSS/CSS (freshwater) & 20.4 \\
\hline [55] FPCSS/CSS (saline water) & 23.6 \\
\hline [56] $3 \mathrm{~mm}$ & 30.71 \\
\hline [56] $4 \mathrm{~mm}$ & 19.02 \\
\hline [56] $5 \mathrm{~mm}$ & 11.44 \\
\hline [57] CSS & 27 \\
\hline [57] FPCSS & 24.5 \\
\hline [59] APSS/CSS & 44.33 \\
\hline [61] CSS & 23 \\
\hline [61] SFPCSS & 15.9 \\
\hline [61] FPCSS & 13.25 \\
\hline [62] $1.8 \mathrm{~kg} / \mathrm{h}$ & 43.71 \\
\hline [62] $3.2 \mathrm{~kg} / \mathrm{h}$ & 38.27 \\
\hline [62] $4.7 \mathrm{~kg} / \mathrm{h}$ & 29.62 \\
\hline [63] FPCSS/CSS & 21 \\
\hline [64] 1 FPCSS & 6.82 \\
\hline [64] 2 FPCSS & 6.93 \\
\hline [64] 3 FPCSS & 5.79 \\
\hline [73] FPCSS/CSS & 12 \\
\hline [73] 5 days & 44.62 \\
\hline [73] 9 days & 56.42 \\
\hline
\end{tabular}

reduces by increasing the condensation chamber area. They showed that for collector areas of 2 and $10 \mathrm{~m} 2$, the distilled water costs are $\$ 0.12$ and $\$ 0.04$, respectively (Figure 20).

Al-Molhem and Eltawil [64] estimated the cost of distilled water per liter for modified and conventional solar stills, which was between $\$ 0.059$ and $\$ 0.062$, respectively.

Al-harahsheh et al. [72], by performing an economic evaluation, showed that their studied desalination units are good for the remote areas. The present worth was $\$ 3794$ /year at the minimum attractive rate of return. They estimated that the payback period is 2.5 years, which is

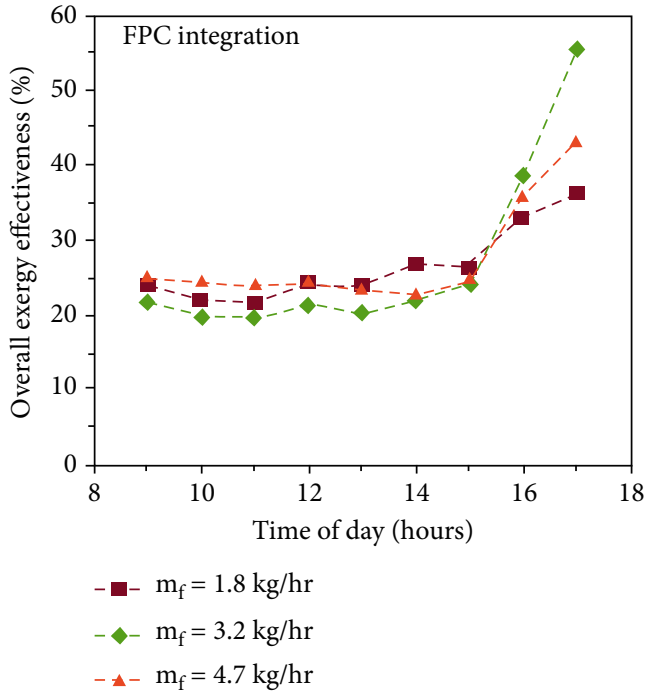

FIGURE 18: Effect of water mass flow rate on the overall exergy efficiency during a day [66].

smaller than 4.6 years; then, this operation is possible. Their results showed that the internal rate of return at an interest rate of $10 \%$ was $32.8 \%$ which is smaller than $10 \%$; the internal rate of return revealed that the desalination was gainful.

Manokar et al. [66] calculated two parameters of energy return and carbon attained of the solar still; it was observed that the estimated payback period and carbon credit at mass flow rates of $1.8,3.2$, and $4.7 \mathrm{~kg} / \mathrm{h}$ are $\$ 21, \$ 25$, and $\$ 30$, respectively.

Eltawil and Omara [67] investigated a cost analysis for the conventional and the developed solar stills for an expected life period of 10 years. They showed that the air solar collector causes lower efficiency and higher cost and complexity. They stated that the total cost of the conventional solar still per $1 \mathrm{~m}^{2}$ is about $\$ 412$ and its total productivity is about $8500 \mathrm{~L}$, obtaining $1 \mathrm{~L}$ a distilled water cost of $\$ 0.049$. Similarly, they noted that the distilled water cost of the developed solar still coupled with a condenser is $\$ 0.056$ and the distilled water cost of the developed solar still coupled with a water solar collector (forced mode) is $\$ 0.066$.

In Figure 21, the cost of the produced freshwater in US dollar per day for different types of solar stills could be observed. The calculated average cost is $0.0646 \%$ in this study, which is a high value among them. The maximum cost is $\$ 0.13$ [70], which refers to a developed solar still coupled with a flat plate collector for small applications. The minimum cost is $\$ 0.0276$ [58], which relates to a solar still coupled with a flat plate collector that proves obtaining freshwater from a conventional solar still is more expensive than that of the solar still coupled with a flat plate collector.

3.7. Productivity Evaluation. Solar stills were built to desalinate contaminated water and collect pure and potable water. All of the applied modifications are aimed at improving their productivity, and many researchers study different affecting parameters in this regard. In this section, the productivity 


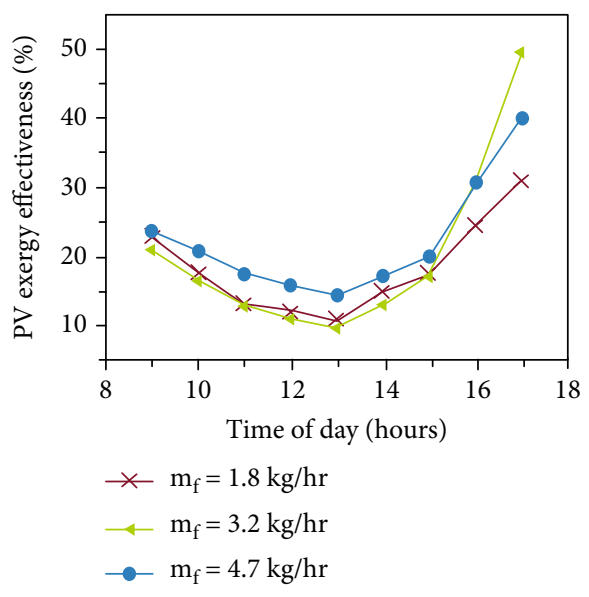

FIGURE 19: Effect of water mass flow rate on the PV exergy efficiency during a day [66].

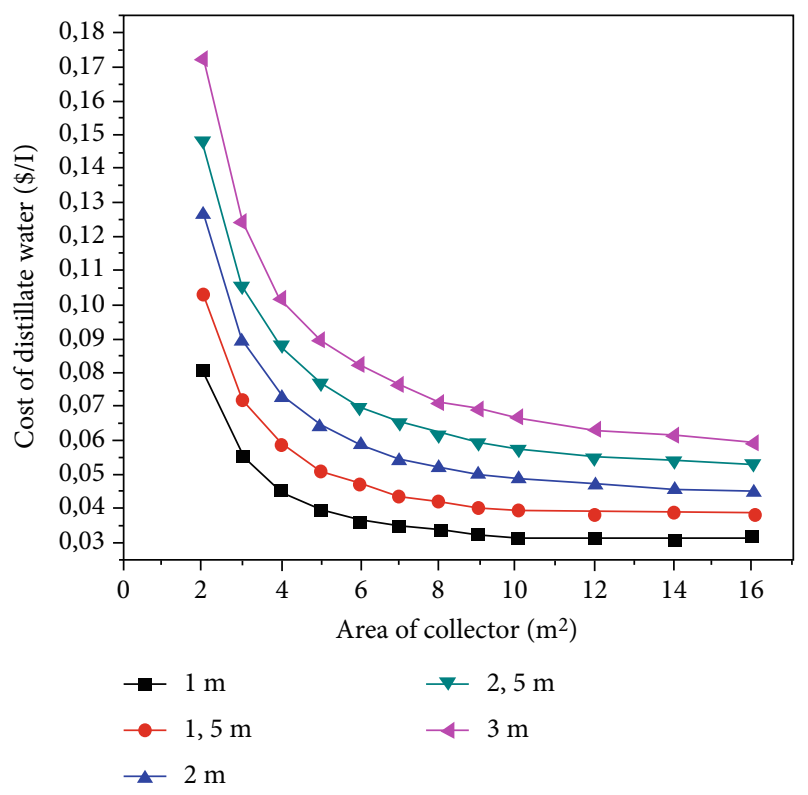

Figure 20: Effect of the collector area on the cost of distilled water [71].

enhancement of solar stills coupled with a flat plate is presented.

Rajaseenivasan et al. [58] showed that the solar still coupled with a flat plate collector obtains $60 \%$ higher distilled water, in comparison to the conventional solar still. Their results showed that the jute cloth applied in the basin increases the productivity in the sunshine hours while the black gravel is more efficient in the afternoon hours. They reported that the productivity of the conventional solar still and that coupled with a flat plate collector are 3.62 and $5.82 \mathrm{~kg} / \mathrm{m}^{2}$ per day, respectively.

Sheeba et al. [59] investigated the effect of coupling a flat plate collector with a solar still system and find that, in comparison with the conventional type, its productivity for fresh and saline waters would be 20.8 and $24.1 \%$ higher, respectively (Figure 22). Productivity of the solar still containing freshwater is $4.1 \%$ higher than that of containing saline water.

Sethi and Dwivedi [70] obtained the annual productivity of a double-slope active solar still in the mode of forced circulation, which showed a reduction while the water depth increases (Table 2).

Khechekhouche et al. [60] measured the productivity of a conventional solar stills at different cover thicknesses of 3,5 , and $6 \mathrm{~mm}$, which were $3.15,2.02$, and $1.13 \mathrm{~kg}$, respectively. That is, the productivity of the solar still with a cover thickness of $3 \mathrm{~mm}$ is $40.48 \%$ and $65.15 \%$ higher than that of the solar still with cover thicknesses of 5 and $6 \mathrm{~mm}$, respectively.

Badran et al. [61] observed that, in comparison to that of the conventional solar still, while feeding tap and saline waters, the productivity of the solar still coupled with a collector increases $231 \%$ and $52 \%$, respectively. They reported that nearly $2 \mathrm{~L} / \mathrm{m}^{2}$ distilled water is obtained from the solar still without a collector. Only about $2 \%$ increment in the productivity was measured in the condition of the solar still coupled with a collector applied from $8 \mathrm{AM}$ to $5 \mathrm{PM}$, in comparison to the conventional solar still.

Abu-Arabi et al. [15] observed that by increasing the solar irradiation from 200 to $700 \mathrm{~W} / \mathrm{m}^{2}$ applying glass cooling, collector, and phase change materials, the productivity of the solar still increases from 0.9 to $3.4,2.35$ to 10 , and 3 to $11.9 \mathrm{~mL} / \mathrm{min}$, respectively. Also, at the coolant mass flow rates between 0 and $10 \mathrm{~kg} / \mathrm{s}$, the productivity increases from 1 to $2.14,1$ to 6.65 , and 1 to $7.5 \mathrm{~mL} / \mathrm{min}$ for the configurations of the solar still applying glass cooling, collector, and phase change materials, respectively. The variation of the hot water circulation rate from 0 to $0.1 \mathrm{~kg} / \mathrm{s}$ causes the productivity to increase from 2.4 to 6 and from 4 to $7.4 \mathrm{~mL} / \mathrm{min}$ for the configurations of the solar still applying collector and phase change materials, respectively. At a constant cooling mass flow rate of 2.1 , for the previously mentioned configurations, the productivity increases from 5.7 to 6.7 and from 6.6 to $7.5 \mathrm{~mL} / \mathrm{min}$, respectively (Figure 23 ).

Baharin and Mohammad [74] investigated the effect of different parameters on the performance of the solar still coupled with a flat plate collector. Their results showed that the flat plate collector has positive effects on the performance, i.e., the productivity will be doubled. Also, they used three different diameters of solid copper rods of 3, 4, and $5 \mathrm{~mm}$ as a solar collector. The obtained results showed that the $5 \mathrm{~mm}$ diameter rod has the highest performance, in comparison to the other applied rods.

Soliman et al. [75] carried out an experimental and theoretical investigation to study the effect of continuous water heating on the solar still basin. They used several components including a flat plate solar collector, solar still with built-in heat exchanger, evacuated tube solar collector, and single solar still. Moreover, three configurations were used to study: (1) conventional solar still, (2) solar still with a heat exchanger coupled with a flat plate collector, and (3) solar still with a heat exchanger coupled with an evacuated tube collector. They found that the productivity of the third configuration is twice that of the first one in the same conditions. They stated that productivity enhancement is due to 


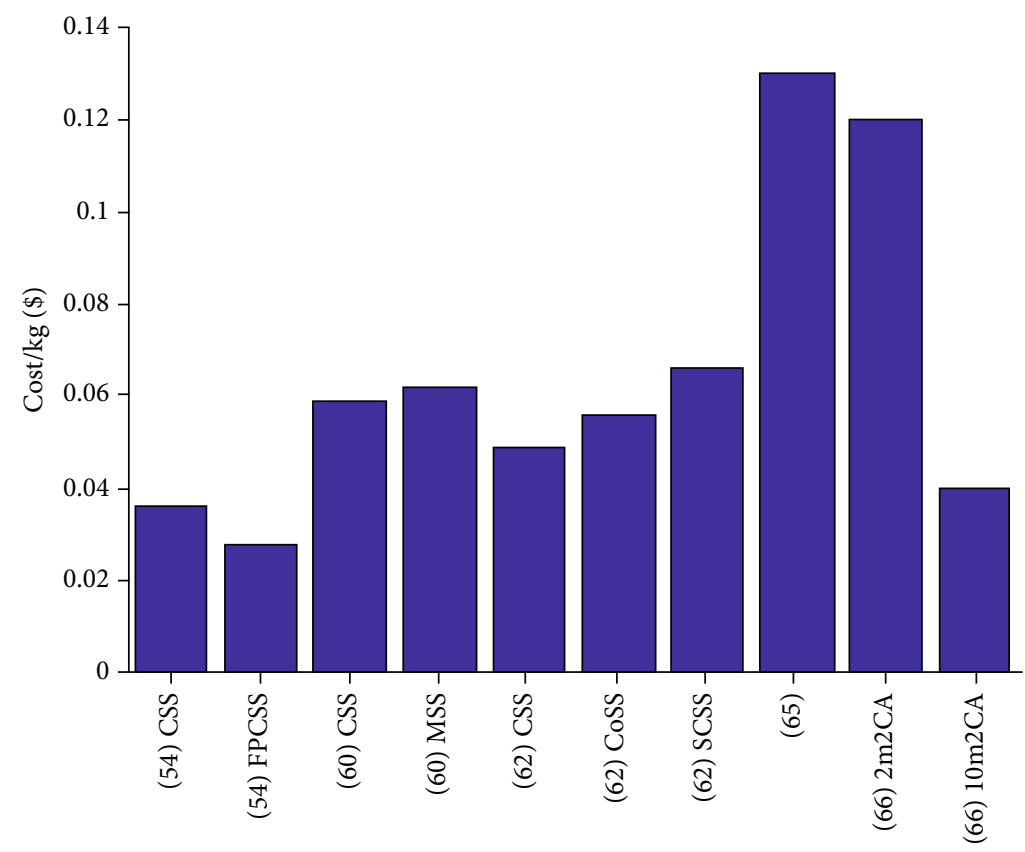

FIgURE 21: Cost of different types of solar stills.

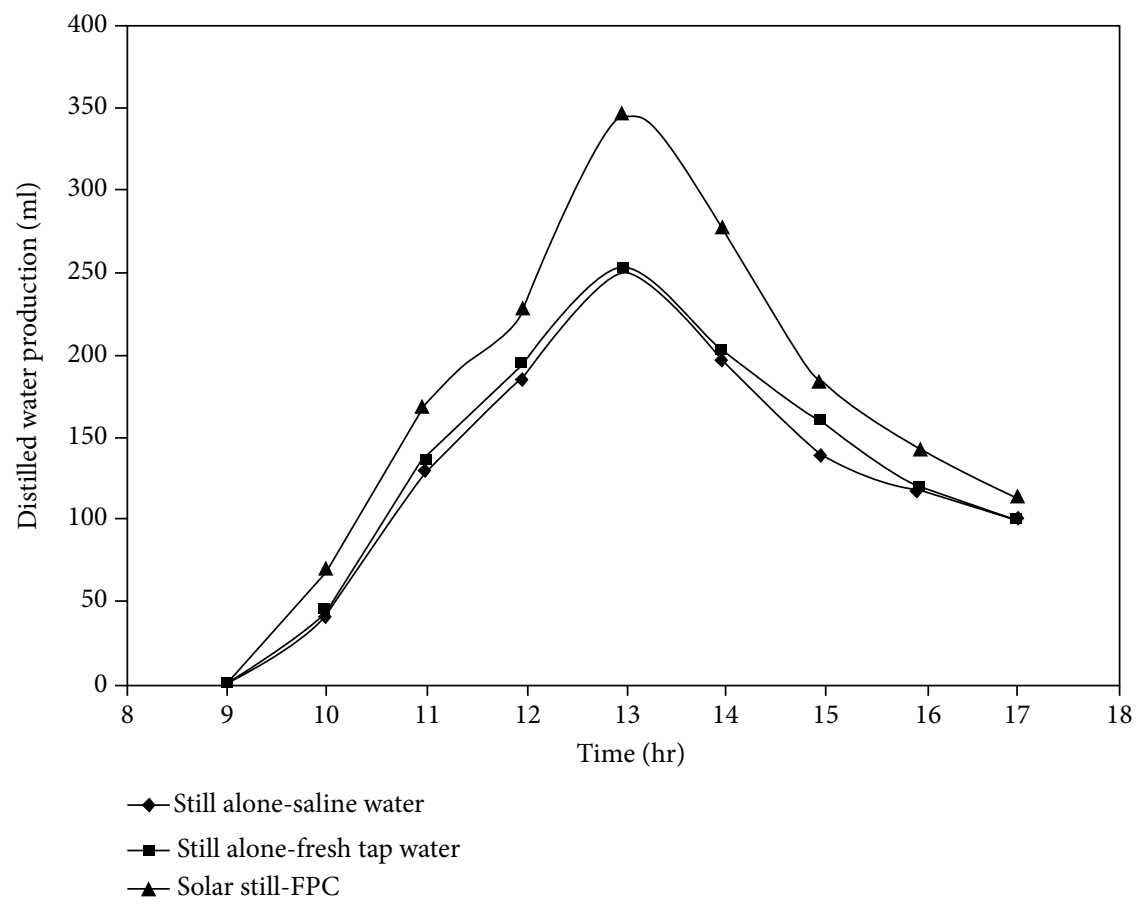

FIGURE 22: Productivity comparison of solar still containing freshwater, saline water, and solar still coupled with a flat plate collector containing freshwater [59].

TABLE 2: Solar still annual yields on the basis of energy for a different water depth [70].

\begin{tabular}{lc}
\hline Water depth $(\mathrm{m})$ & Annual yield on the basis of energy $(\mathrm{kg})$ \\
\hline 0.03 & 1337 \\
0.04 & 1253 \\
0.05 & 1176 \\
\hline
\end{tabular}

the continuous water heater obtained from the heat exchanger. Also, the overall productivity of the third configuration is $6.45 \mathrm{~kg} / \mathrm{m}^{2} / 12 \mathrm{hrs}$. They concluded that coupling the solar still with a flat plate collector has negative effect while using an evacuated tube has a positive effect on the solar still's productivity only in a closed loop.

Badran and Al-Tahaineh [13] experimentally studied the application of flat plate collector on the solar still's 


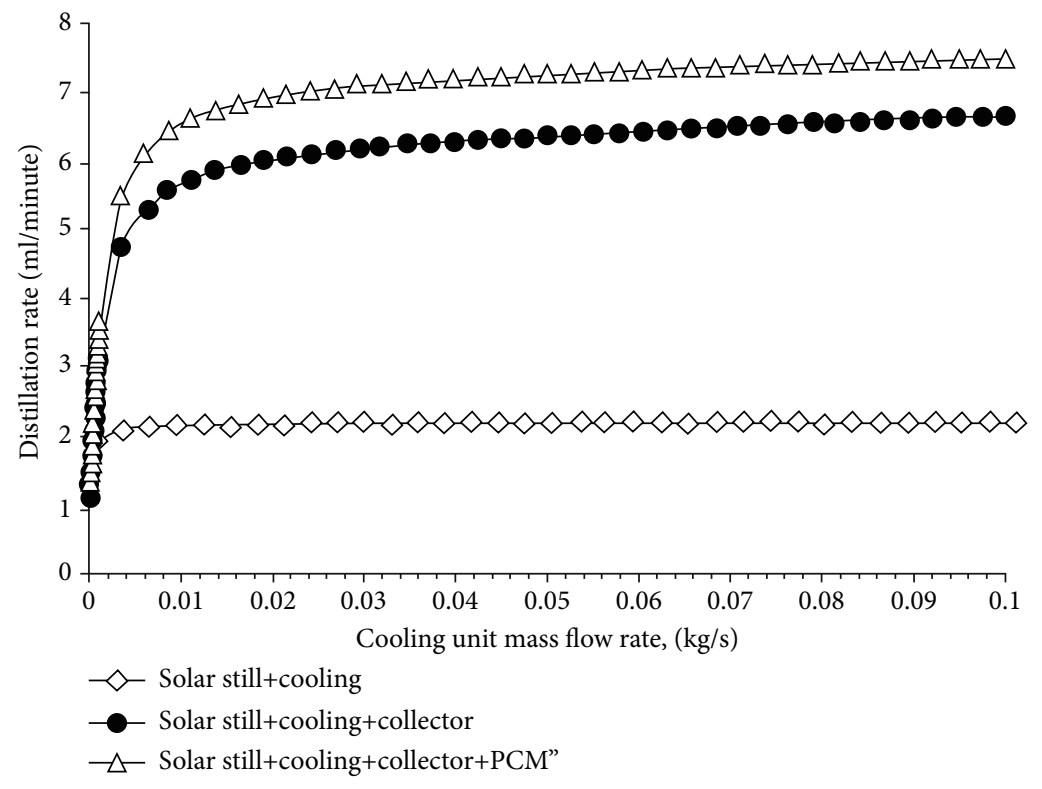

FIGURE 23: Cooling mass flow rate effect on the productivity [15].

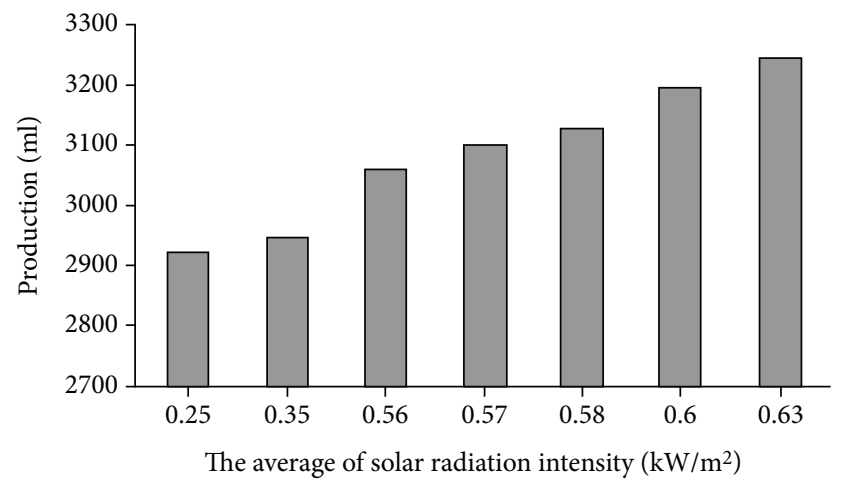

FIgURE 24: The relation between solar intensity and productivity [13].

productivity. Moreover, they investigated the effect of other dominant parameters on productivity including solar radiation, water depth, and still direction. They used mirrors which are fixed inside of the solar still. Their results showed that productivity increases by 36\% using a flat plate collector in the solar still, while water depth leads reduction of the productivity. Solar radiation and productivity were changed proportionally to each other (Figure 24).

Abu-Arabi et al. [73] theoretically modeled a solar still coupled with a collector and phase change material to simulate the solar still performance. They used sodium thiosulfate pentahydrate as a phase change material in their investigations to continue distillation of water during nighttime by transferring energy to basin water. A good agreement between the theoretical and experimental results regarding productivity and temperature profiles of the basin water was shown. They observed that the productivity decreases by up to $30 \%$ by increasing the ratio of the phase change material to water mass from 10 to $100 \%$. Therefore, higher phase change material mass leads to less productivity. It is observed that decreasing the heat transfer coefficient from 10.4 to $2.6 \mathrm{~W} / \mathrm{m}^{2} \cdot \mathrm{K}$ results in the increase of productivity by more than $100 \%$. Moreover, they studied the effect of glass cover cooling on the productivity, which shows an enhancement of $37 \%$ while increasing the flow rate from 0.01 to $0.1 \mathrm{~kg} / \mathrm{s}$ (Figure 25).

Feilizadeh et al. [62] showed that a basin coupled with a solar collector with a CBA of 3.45 generates $11.56 \mathrm{~kg}$ distillated water in the winter. By applying CBA of 6.90 and 10.35 (the second and third collectors), the obtained productivity will be $96 \%$ and $23 \%$, respectively. Moreover, adding the second and third collector leads to $48 \%$ and $23 \%$ higher productivity in the summer, respectively (Figure 26).

Kerfah et al. [71] revealed that the increasing collector area leads to higher evaporated water which obtains higher freshwater. They obtained annual freshwater of 482.35 and 2083.65 L for collector areas of 2 and $10 \mathrm{~m}^{2}$, respectively (Figure 27).

Mousa and Abu Arabi [76] designed a solar still coupled with an external solar collector to produce hot and distilled water. Three main parts were used in their equipment including a heat exchanger, water basin, and external solar collector. Basin water temperature was raised with direct solar irradiation and hot water in which its temperature was increased by the external solar collector. Vapor condensation was accomplished applying cooling water flows on the double-glass cover. They studied the effect of several parameters on the productivity including solar intensity, cooling water flow rate, ambient temperature, and hot water production. Their results revealed that the distilled production rate slightly decreases by hot water production. Producing $0.4 \mathrm{~L} / \mathrm{h}$ of distilled water and raising the water temperature to $87^{\circ} \mathrm{C}$ during the summer period were their significant outcomes. Also, they found that the productivity increases, while increasing the cooling water flow rate up to a certain 


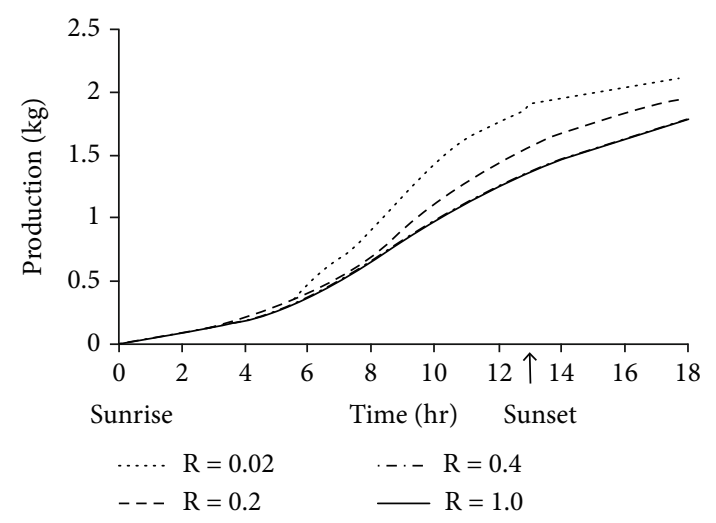

(a)

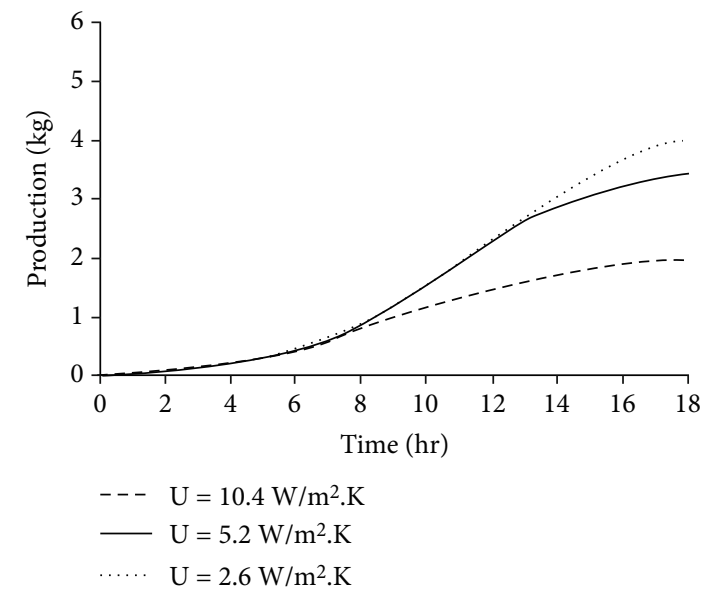

(b)

FIGURE 25: Productivity affected by (a) the ratio of the phase change material mass to water mass and (b) the heat transfer coefficient [73].

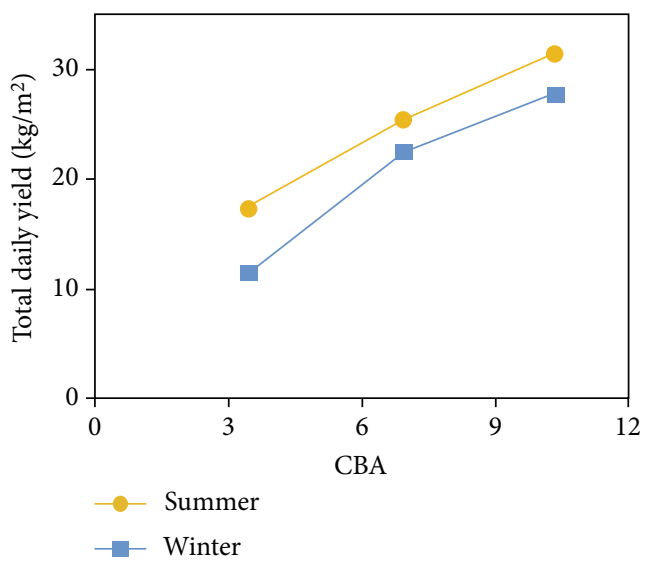

Figure 26: Effect of CBA on the total daily yield [62].

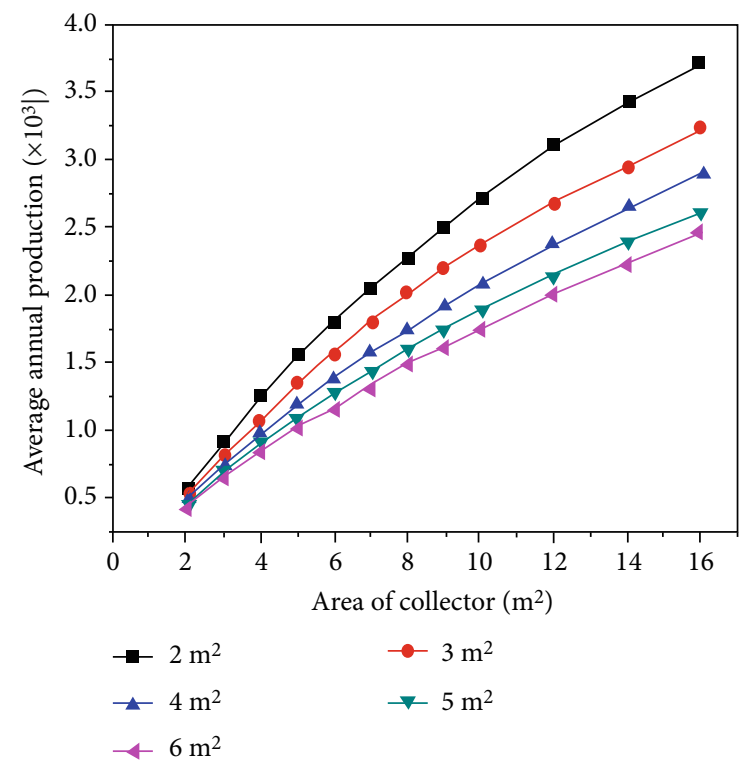

Figure 27: Effect of the collector area on the fresh water production [71]. flow rate, and after that, it does not change. Moreover, in the closed loop cycle, while applying the forced circulation at medium and high speeds, the amount of distilled water enhances up to 7 and $27 \%$, respectively.

Kumar et al. [63] found that increasing the wind speed and the air-packed layer has a positive effect on the solar still productivity and has negative effect on that performance. They proposed that the cover temperature should be exactly investigated to get higher distilled water applying the cover cooling techniques. The productivity of air-packed pyramid solar still increases by $6.54 \%$, in comparison to that of the conventional double-glass solar still (Figures 28 and 29).

Poblete et al. [77] designed a solar still to study some parameters, including applying different cover materials, adding mirrors, activating an air extractor, heating the basin, and applying a black-painted floor. They combined the aforementioned factors, which show the best performance of the brine evaporation. The parameters of the brine volume, brine mass, temperature variation, and incident radiation were daily monitored. They calculated the accumulation of solar energy and proposed a correlation. Their results revealed that using a mirror and heating the basin are the most efficient factors while the glass cover material is the least one. The evaporation performance adversely affects the air extractor. They found that the evaporation rate inside the solar still is $36.7 \%$, while it is $13.3 \%$ outside of it. A significant finding of their results was higher drying performance of the solar still due to brine dewatering.

Al-Molhem and Eltawil [64] observed that the northern side of the solar still has higher productivity in comparison to its southern side by $33.98 \%$ for the east-west orientation and preheating of the solar still. By using modifications including preheating, floatable black wicks, and the east-west orientation, the productivity increases by $45.65 \%$, in comparison to the conventional solar still. The average efficiencies of the modified solar still at the southern and northern sides were 25.33 and $37.25 \%$, while they were 13.87 and $30.73 \%$ for the conventional solar still, respectively. 


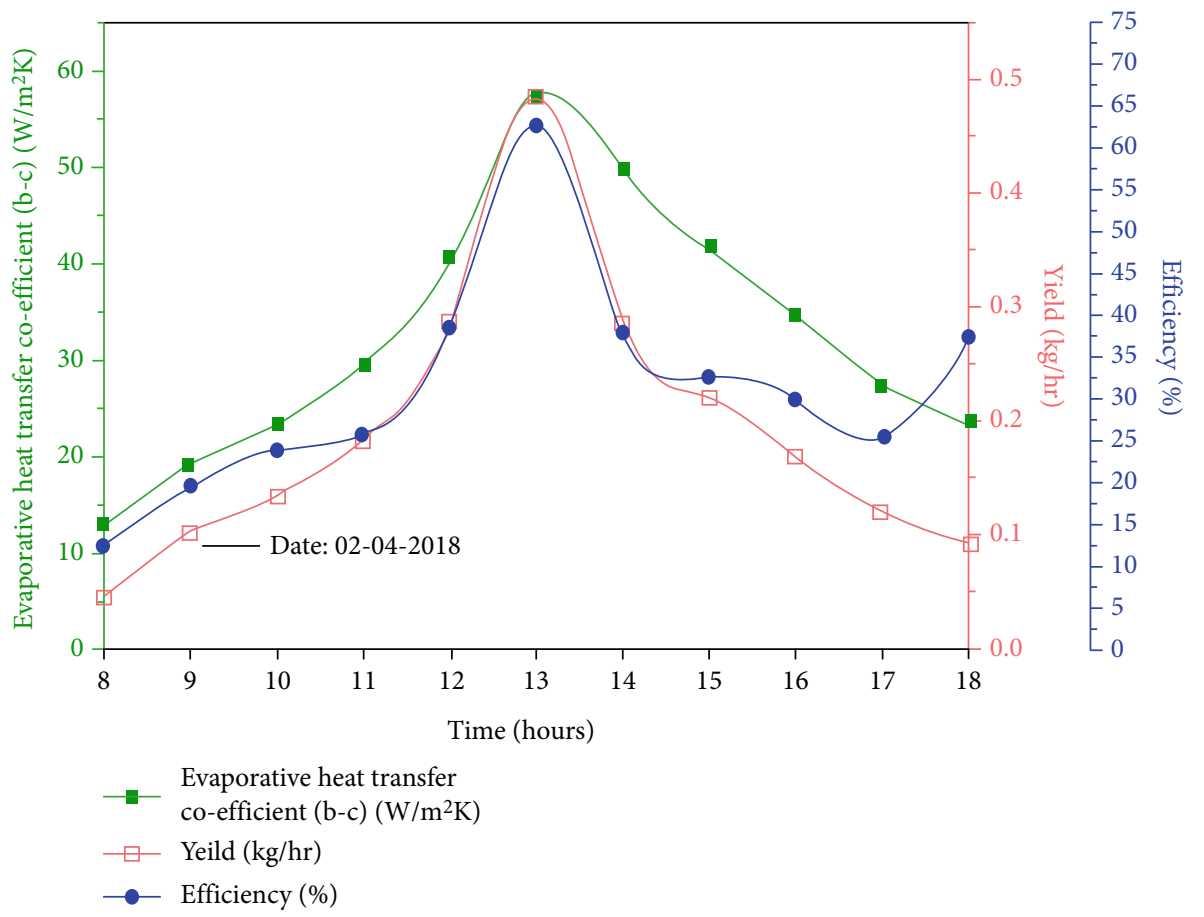

Figure 28: Efficiency, productivity, and evaporative heat transfer coefficient of the conventional pyramid shape solar still [63].
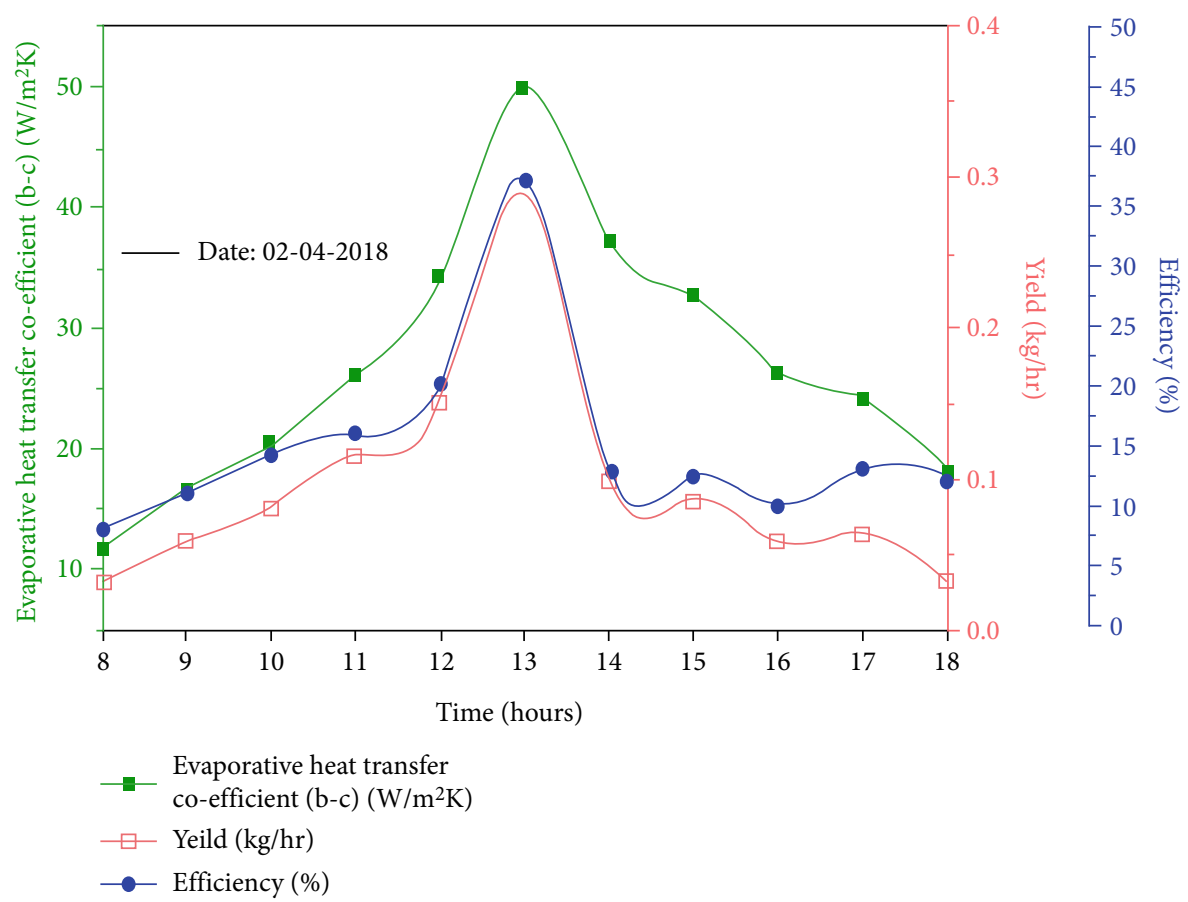

FiguRE 29: Efficiency, productivity, and evaporative heat transfer coefficient of the air-packed pyramid shape solar still [63].

Al-harahsheh et al. [72] desalinated saline water using the solar still applying a double-glass cover coupled with a solar collector and phase change material. They used a phase change material as thermal storage to store energy for providing energy in the nighttime. Some parameters such as the basin water level, hot water circulation flow rate, and cooling water flow rate were studied. It is found that the pro- duction rate is proportional to the ambient temperature increment and hot water circulation flow rate. They reported that the best cooling water flow rate for higher productivity is about $10 \mathrm{~mL} / \mathrm{s}$. Also, the water level has a negative effect on the productivity, i.e., it decreases the productivity. Their results showed that the productivity per day is $4300 \mathrm{~mL} / \mathrm{m}^{2}$, in which $40 \%$ of it is obtained at 


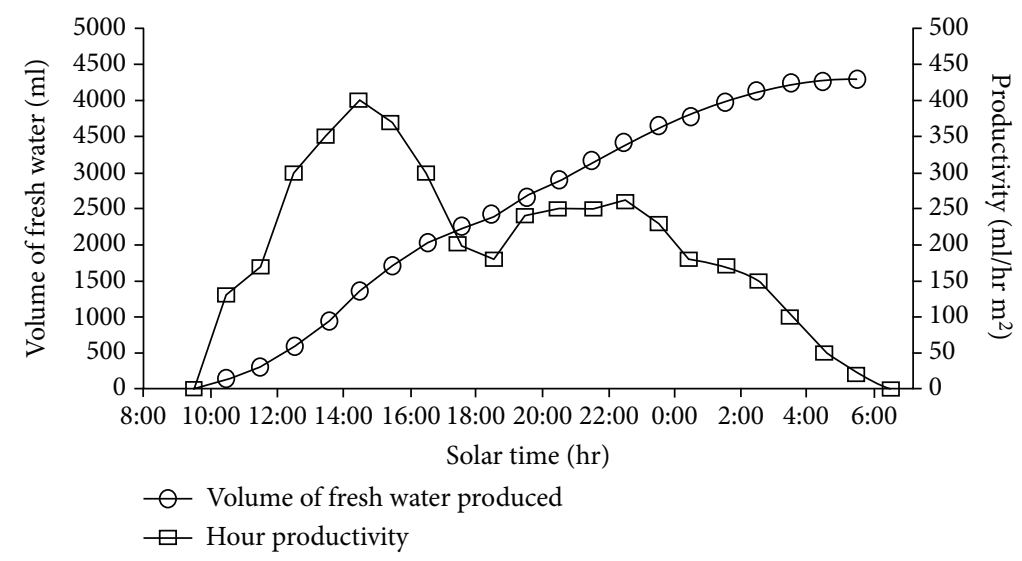

Figure 30: Productivity and freshwater volume vs. solar time [72].

night. The productivity is tripled by increasing the circulation hot water flow rate from 2 to $30 \mathrm{~mL} / \mathrm{s}$. The effect of the phase change material was higher at lower water levels in the basin, i.e., decreasing the water level from 10 to $5 \mathrm{~cm}$ increases the productivity to became double (Figure 30).

MohanRai et al. [65] showed that the conventional solar still has a productivity of $2.1 \mathrm{~kg} /$ day, while that of the solar still coupled with a single collector is $4.75 \mathrm{~kg} /$ day and that for the solar still coupled with a series of the collector is $6.5 \mathrm{~kg} /$ day. The solar still coupled with a single collector showed $126 \%$ higher productivity than the conventional one.

Manokar et al. [66] studied the effect of the water mass flow rate on freshwater productivity. They showed that at water mass flow rates of $1.8,3.2$, and $4.7 \mathrm{~kg} / \mathrm{h}$, the productivity of 7.5, 6.5, and $5.4 \mathrm{~kg}$ will be obtained, respectively.

Balamurugan et al. [78] investigated the brine depth on the performance of the solar still. They fabricated three types of solar stills which have an area of $1 \mathrm{~m}^{2}$ and five different fine depths of $1,4,6,8$, and $10 \mathrm{~cm}$. They used an evacuated tube collector and flat plate collector coupled with a solar still and compared the obtained distilled water with that of the conventional one. Their results revealed that increasing the brine depth yields productivity reduction. Also, the solar still coupled with evacuated tube collector showed higher productivity for all brine depths. They stated that the evacuated tube collector preheats water at higher efficiency, in comparison to the flat plate collector due to thermal losses. They observed that the maximum basin water temperatures in January and June with a $1 \mathrm{~cm}$ level of the basin depth for the solar still coupled with an evacuated tube collector, the solar still coupled with flat plate collector, and the conventional solar still are 85,76 , and $61^{\circ} \mathrm{C}$, respectively, and 87 , 79 , and $65^{\circ} \mathrm{C}$, respectively.

Rai and Tiwari [79] considered the transient performance of the conventional solar still coupled with a flat plate collector. They showed that the productivity of the integrated solar still unit is $24 \%$ higher than that of the conventional solar still. Their results showed that the productivity of both solar stills increases by increasing the insulation thickness up to $4 \mathrm{~cm}$. Moreover, adding dye into the water results in the conventional solar still absorbing higher dis-

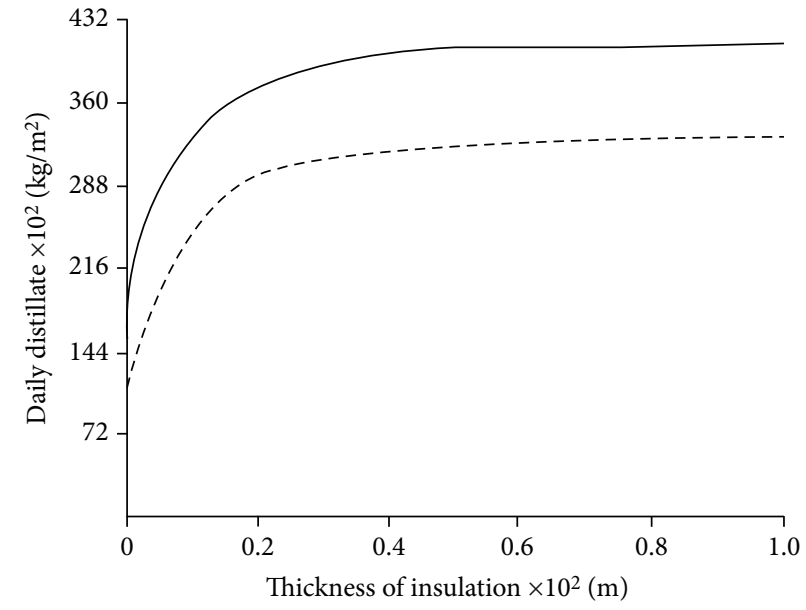

Figure 31: Effect of insulation thickness on distilled water (continuous line for the coupled solar still and dotted line for the conventional solar still) [79].

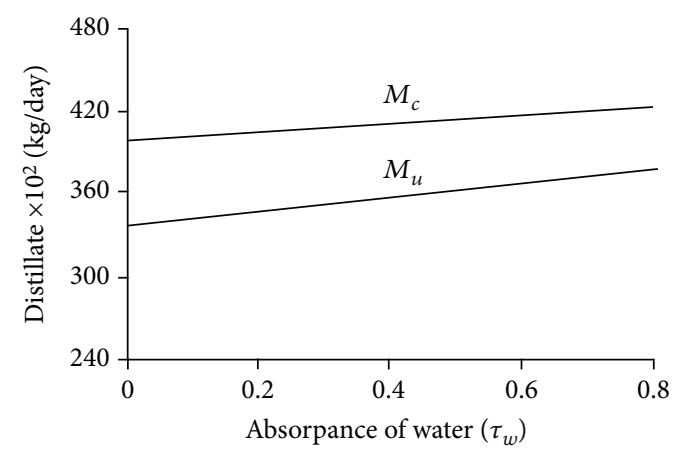

FIgURE 32: Effect of water absorbance on distilled water $\left(M_{c}\right.$ for the coupled solar still and $M_{u}$ for the conventional solar still) [79].

tilled water, in comparison to the solar still coupled with flat plate collector (Figures 31 and 32).

Eltawil and Omara [67] showed that the solar still coupled with an air collector and condenser has $60 \%$ higher productivity, in comparison to the conventional solar still. Moreover, the productivity of the equivalent conventional 


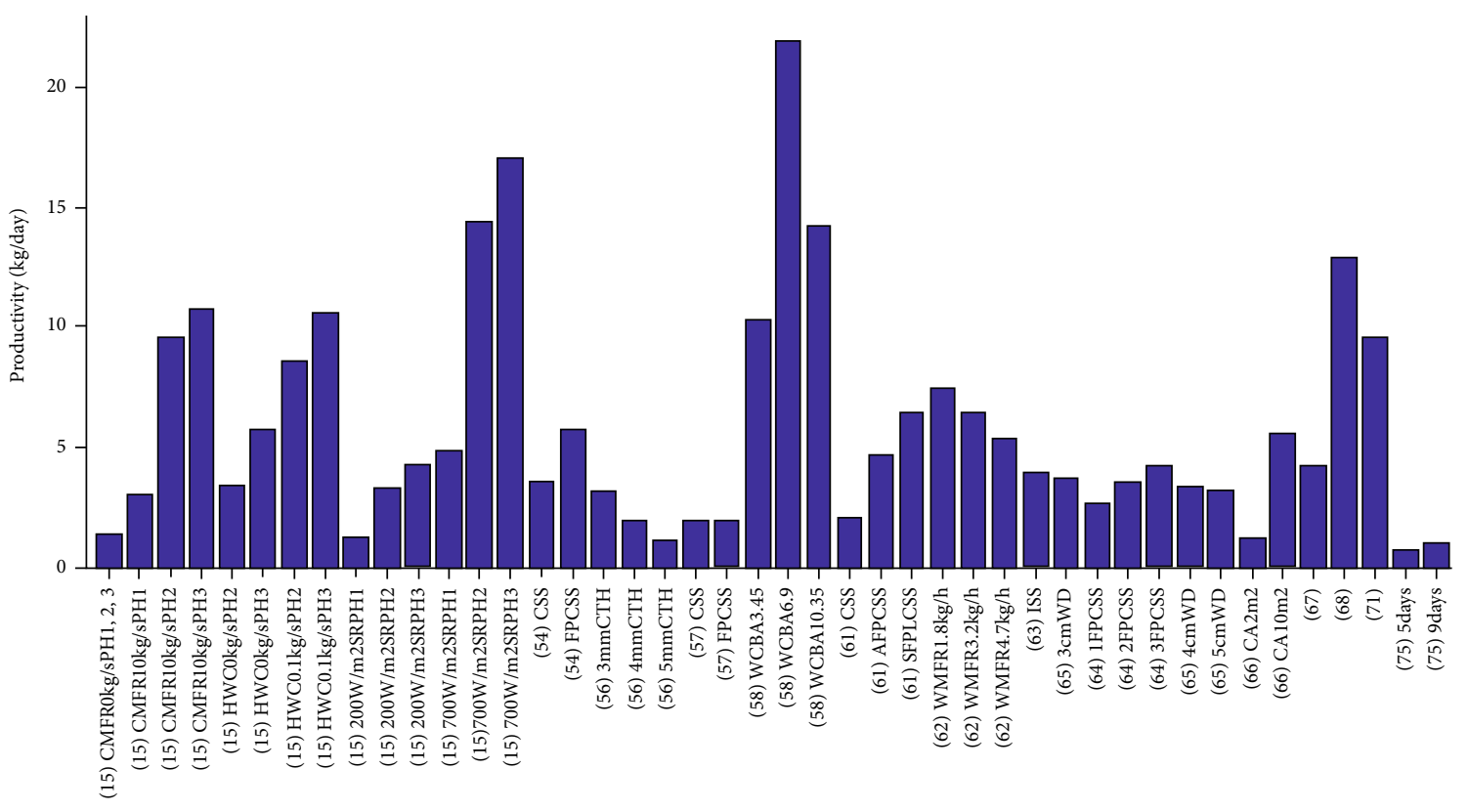

FIgURe 33: Productivity of different types of solar stills.

solar still was $175 \%$ higher than that of the developed solar still (a solar still which has all equipment). Coupling the solar still with solar collector and condenser shows 104\% and $141 \%$ higher performance as passive and active circulation using a hot water spray and $132 \%$ higher performance as active circulation using a hot water jet. Applying hot water circulation (using a flat plate collector) without a condenser in integrated and conventional solar stills shows $82 \%$ and 56\% higher productivity, respectively, while applying a hot water jet shows $76 \%$ enhancement. Coupling the solar still with hot water spray, condenser, and hot air yields $148 \%$ higher performance, in comparison to the conventional solar still. The measured productivity of the integrated solar still is between 3 and $4 \mathrm{~L} / \mathrm{m}^{2}$ which is $51-148 \%$ higher than the conventional one, depending on the equipment applied. Also, the solar still coupled with an external condenser has 51\% higher productivity. They estimated that the productivity of equivalent conventional solar still is about $142 \%$ higher than that of the developed solar still.

Narayana and Raju [68] showed that the productivity rates of the solar still coupled with one, two, and three flat plate collectors are $2.669,3.581$, and $4.229 \mathrm{~kg}$, respectively. In comparison to the solar still coupled with one flat plate collector, coupling with 2 and 3 flat plate collectors shows $34.17 \%$ and $58.45 \%$ higher productivity, respectively.

Menon [69] revealed that the maximum productivity rates in his research are 720 and $1070 \mathrm{~mL}$ in different periods of five and nine days, respectively.

Productivity of different configurations of the solar stills is shown in Figure 33 and Table 3 . The average productivity of these reviewed researches is $5.87 \mathrm{~kg}$ per day, and the productivity of a few investigations is higher than 5.87. It sounds that this average is reasonable in small domestic applications. The maximum recorded productivity of $21.96 \mathrm{~kg}$ was reported in reference [62], which studied the effect of the collector-to-basin area ratio on the performance of a multistage solar still. Using a CBA of 6.90 enhances the productivity by $96 \%$, while applying higher CBA (that is, 10.35) obtains lower productivity. However, a minimum of 5 days of productivity of 0.72 was reported in reference [69] which is obtained by applying a solar still coupled with a flat plate collector.

\section{Conclusions and Suggestions}

In the solar stills, the solar energy is used to desalinate water. Since a conventional solar still has low productivity, some other components such as flat plate collectors are coupled to it. These collectors are used to increase the saline water temperature before its entrance into the solar still as a preheater. In this research, considering energy analysis, exergy analysis, economic analysis, and productivity evaluation, the solar stills coupled with flat plate collectors are investigated. The key findings of the reviewed researches are as follows:

(i) A maximum efficiency of $60 \%$ could be obtained by applying a solar still coupled with flat plate collectors which use six small compartments in the basin to increase the evaporation rate

(ii) A minimum efficiency of $5.69 \%$ could be obtained by using three flat plate collectors coupled with a solar still

(iii) The maximum cost of a solar still coupled with a flat plate collector for small applications is $\$ 0.13$

(iv) The minimum cost of a solar still coupled with a flat plate collector is $\$ 0.0276$ 
TABLE 3: Solar still productivity of studied references.

\begin{tabular}{|c|c|}
\hline Reference & Productivity (kg) \\
\hline [15] CMFR $0 \mathrm{~kg} / \mathrm{s}$ PH1,2,3 & 1.44 \\
\hline [15] CMFR $10 \mathrm{~kg} / \mathrm{s}$ PH1 & 3.1 \\
\hline [15] CMFR $10 \mathrm{~kg} / \mathrm{s} \mathrm{PH} 2$ & 9.6 \\
\hline [15] CMFR $10 \mathrm{~kg} / \mathrm{s} \mathrm{PH} 3$ & 10.8 \\
\hline [15] HWC $0 \mathrm{~kg} / \mathrm{s}$ PH2 & 3.45 \\
\hline [15] HWC $0 \mathrm{~kg} / \mathrm{s}$ PH3 & 5.76 \\
\hline [15] HWC 0.1 kg/s PH2 & 8.64 \\
\hline [15] HWC 0.1 kg/s PH3 & 10.65 \\
\hline [15] $200 \mathrm{~W} / \mathrm{m}^{2} \mathrm{SRPH} 1$ & 1.3 \\
\hline [15] $200 \mathrm{~W} / \mathrm{m}^{2} \mathrm{SRPH} 2$ & 3.4 \\
\hline [15] $200 \mathrm{~W} / \mathrm{m}^{2} \mathrm{SRPH} 3$ & 4.3 \\
\hline [15] $700 \mathrm{~W} / \mathrm{m}^{2} \mathrm{SRPH} 1$ & 4.9 \\
\hline [15] $700 \mathrm{~W} / \mathrm{m}^{2} \mathrm{SRPH} 2$ & 14.4 \\
\hline [15] $700 \mathrm{~W} / \mathrm{m}^{2} \mathrm{SRPH} 3$ & 17.1 \\
\hline [54] CSS & 3.62 \\
\hline [54] FPCSS & 5.82 \\
\hline [56] $3 \mathrm{~mm} \mathrm{CTH}$ & 3.15 \\
\hline [56] $4 \mathrm{~mm} \mathrm{CTH}$ & 2.02 \\
\hline [56] $5 \mathrm{~mm} \mathrm{CTH}$ & 1.13 \\
\hline [57] CSS & 2 \\
\hline [57] FPCSS & 2.04 \\
\hline [58] WCBA3.45 & 10.35 \\
\hline [58] WCBA6.9 & 21.96 \\
\hline [58] WCBA10.35 & 14.21 \\
\hline [61] CSS & 2.1 \\
\hline [61] AFPCSS & 4.75 \\
\hline [61] SFPLCSS & 6.5 \\
\hline [62] WMFR $1.8 \mathrm{~kg} / \mathrm{h}$ & 7.5 \\
\hline [62] WMFR $3.2 \mathrm{~kg} / \mathrm{h}$ & 6.5 \\
\hline [62] WMFR $4.7 \mathrm{~kg} / \mathrm{h}$ & 5.4 \\
\hline [63] ISS & 4 \\
\hline [65] $3 \mathrm{~cm} \mathrm{WD}$ & 3.7 \\
\hline [64] 1 FPCSS & 2.67 \\
\hline [64] 2 FPCSS & 3.6 \\
\hline [64] 3 FPCSS & 4.23 \\
\hline [65] $4 \mathrm{~cm} \mathrm{WD}$ & 3.4 \\
\hline [65] $5 \mathrm{~cm} \mathrm{WD}$ & 3.2 \\
\hline [66] CA $2 \mathrm{~m}^{2}$ & 1.3 \\
\hline [66] CA $10 \mathrm{~m}^{2}$ & 5.7 \\
\hline$[67]$ & 4.3 \\
\hline$[68]$ & 12.9 \\
\hline [71] & 9.6 \\
\hline [73] 5 days & 0.72 \\
\hline [73] 9 days & 1.07 \\
\hline
\end{tabular}

(v) The maximum productivity of $21.96 \mathrm{~kg}$ could be obtained by enhancing the collector-to-basin area ratio in a multistage solar still (vi) The minimum productivity of $0.72 \mathrm{~kg}$ was recorded applying a solar still coupled with a flat plate collector

(vii) Decreasing the glass cover thickness of the solar still significantly enhances the energy efficiency and productivity

(viii) The thermal efficiency of the air-packed pyramid solar still is higher than the conventional doubleglass solar still

(ix) Increasing the mass flow rates reduces of exergy efficiency

(x) The cost of distilled water which results from a solar still coupled with flat plate collector is lower than that of the conventional one

(xi) Increasing the collector area leads to a lower distilled water cost and the amount of freshwater reduces while the condensation chamber area increases

(xii) The productivity decreases by increasing the water depth

(xiii) Increasing the collector area leads to higher evaporated water and a higher amount of freshwater

(xiv) In water distillation, applying a mirror and heating the basin are the most efficient factor while the glass cover material is the least one

(xv) The solar still coupled with air collector and condenser shows higher productivity

(xvi) Coupling the solar still with a hot water spray, condenser, jet hot water, and hot air has a higher performance, in comparison to the conventional solar still

(xvii) The productivity of the solar stills enhances by increasing the insulation thickness

(xviii) In the conventional solar still, using dye in the water increases the amount of distilled water, in comparison to that in the solar still coupled with a flat plate collector

(xix) The production rate is proportionate with the ambient temperature increment and hot water circulation flow rate

(xx) By increasing the circulation of the hot water flow rate, the productivity enhances

(xxi) At the low water level in the basin, phase change materials could increase the productivity

Finally, to enhance the solar still efficiency and productivity, the following suggestions are presented:

(i) The solar still and solar collector can be made in the form of a cavity shape; therefore, the solar radiation 
could be trapped and energy loss and reflection become the least

(ii) Drain out the air inside the solar still, so that it becomes a mixed saturation. It may enhance the evaporation and condensation rates, so higher distilled water could be collected

(iii) Cool the glass cover with the saline water before entering the solar still. Therefore, the condensation rate and temperature of the saline water are enhanced

(iv) Applying air-packed or other low-conductivity gases, reduces the energy loss from the solar still

\section{Data Availability}

The data supporting this review are from previously reported studies and datasets, which have been cited.

\section{Conflicts of Interest}

The authors declare that they have no conflicts of interest.

\section{References}

[1] H. Lv, Y. Wang, L. Wu, and Y. Hu, "Numerical simulation and optimization of the flash chamber for multi-stage flash seawater desalination," Desalination, vol. 465, pp. 69-78, 2019.

[2] R. Tariq, N. A. Sheikh, J. Xamán, and A. Bassam, "An innovative air saturator for humidification-dehumidification desalination application," Applied Energy, vol. 228, pp. 789-807, 2018.

[3] M. A. Jamil and S. M. Zubair, "Design and analysis of a forward feed multi-effect mechanical vapor compression desalination system: an exergo-economic approach," Energy, vol. 140, pp. 1107-1120, 2017.

[4] W. He, W. Zhu, J. Xia, and D. Han, "A mechanical vapor compression desalination system coupled with a transcritical carbon dioxide Rankine cycle," Desalination, vol. 425, pp. 1-11, 2018.

[5] D. Zhao, J. Xue, S. Li, H. Sun, and Q.-d. Zhang, "Theoretical analyses of thermal and economical aspects of multi-effect distillation desalination dealing with high-salinity wastewater," Desalination, vol. 273, no. 2-3, pp. 292-298, 2011.

[6] S. Azimibavil and A. J. Dehkordi, "Dynamic simulation of a multi-effect distillation (MED) process," Desalination, vol. 392, pp. 91-101, 2016.

[7] A. de la Calle, J. Bonilla, L. Roca, and P. Palenzuela, "Dynamic modeling and performance of the first cell of a multi-effect distillation plant," Applied Thermal Engineering, vol. 70, no. 1, pp. 410-420, 2014.

[8] C. Fritzmann, J. Löwenberg, T. Wintgens, and T. Melin, "State-of-the-art of reverse osmosis desalination," Desalination, vol. 216, no. 1-3, pp. 1-76, 2007.

[9] S. Zhao and Z. Wang, "A loose nano-filtration membrane prepared by coating HPAN UF membrane with modified PEI for dye reuse and desalination," Journal of Membrane Science, vol. 524, pp. 214-224, 2017.

[10] Y. Sano, X. Bai, S. Amagai, and A. Nakayama, "Effect of a porous spacer on the limiting current density in an electro- dialysis desalination," Desalination, vol. 444, pp. 151-161, 2018.

[11] H. E. Fath, M. El-Samanoudy, K. Fahmy, and A. Hassabou, "Thermal-economic analysis and comparison between pyramid-shaped and single- slope solar still configurations," Desalination, vol. 159, no. 1, pp. 69-79, 2003.

[12] L. Mu, X. Xu, T. Williams et al., "Enhancing the performance of a single-basin single-slope solar still by using Fresnel lens: experimental study," Journal of Cleaner Production, vol. 239, p. 118094, 2019.

[13] O. Badran and H. Al-Tahaineh, "The effect of coupling a flatplate collector on the solar still productivity," Desalination, vol. 183, no. 1-3, pp. 137-142, 2005.

[14] M. Morad, H. A. El-Maghawry, and K. I. Wasfy, "Improving the double slope solar still performance by using flat-plate solar collector and cooling glass cover," Desalination, vol. 373, pp. 1-9, 2015.

[15] M. Abu-Arabi, M. Al-harahsheh, M. Ahmad, and H. Mousa, "Theoretical modeling of a glass-cooled solar still incorporating PCM and coupled to flat plate solar collector," Journal of Energy Storage, vol. 29, p. 101372, 2020.

[16] Y. P. Yadav, "Analytical performance of a solar still integrated with a flat plate solar collector: thermosiphon mode," Energy Conversion and Management, vol. 31, no. 3, pp. 255-263, 1991.

[17] S. Abdallah and O. Badran, "Sun tracking system for productivity enhancement of solar still," Desalination, vol. 220, no. 1-3, pp. 669-676, 2008.

[18] Y. Taamneh and M. M. Taamneh, "Performance of pyramidshaped solar still: experimental study," Desalination, vol. 291, pp. 65-68, 2012.

[19] R. Fallahzadeh, L. Aref, N. Gholamiarjenaki, Z. Nonejad, and M. Saghi, "Experimental investigation of the effect of using water and ethanol as working fluid on the performance of pyramid-shaped solar still integrated with heat pipe solar collector," Solar Energy, vol. 207, pp. 10-21, 2020.

[20] A. E. Kabeel, A. M. Hamed, and S. A. El-Agouz, "Cost analysis of different solar still configurations," Energy, vol. 35, no. 7, pp. 2901-2908, 2010.

[21] M. Eltaweel, A. A. Abdel-Rehim, and H. Hussien, "Indirect thermosiphon flat-plate solar collector performance based on twisted tube design heat exchanger filled with nanofluid," International Journal of Energy Research, vol. 44, no. 6, pp. 4269-4278, 2020.

[22] Y. Amirgaliyev, M. Kunelbayev, T. Ormanov, T. Sundetov, and S. Daulbayev, "Experimental comparative analysis of operating characteristics of double circuit flat-plate solar collector with thermosiphon circulation and flat solar collector with chemical coating," Thermal Science, vol. 26, pp. 173-173, 2021.

[23] K. Balaji, S. Iniyan, and M. V. Swami, "Exergy, economic and environmental analysis of forced circulation flat plate solar collector using heat transfer enhancer in riser tube," Journal of Cleaner Production, vol. 171, pp. 1118-1127, 2018.

[24] K. Balaji, S. Iniyan, and V. Muthusamyswami, "Experimental investigation on heat transfer and pumping power of forced circulation flat plate solar collector using heat transfer enhancer in absorber tube," Applied Thermal Engineering, vol. 112, pp. 237-247, 2017.

[25] H. Garg and R. Agarwal, "Some aspects of a PV/T collector/forced circulation flat plate solar water heater with solar cells," Energy Conversion and Management, vol. 36, no. 2, pp. 87-99, 1995. 
[26] S. Kumar and S. Mullick, "Glass cover temperature and top heat loss coefficient of a single glazed flat plate collector with nearly vertical configuration," Ain Shams Engineering Journal, vol. 3, no. 3, pp. 299-304, 2012.

[27] M. Khoukhi and S. Maruyama, "Theoretical approach of a flatplate solar collector taking into account the absorption and emission within glass cover layer," Solar Energy, vol. 80, no. 7, pp. 787-794, 2006.

[28] M. Khoukhi, S. Maruyama, A. Komiya, and M. Behnia, "Flatplate solar collector performance with coated and uncoated glass cover," Heat Transfer Engineering, vol. 27, no. 1, pp. 46-53, 2006.

[29] S. A. Sakhaei and M. S. Valipour, "Investigation on the effect of different coated absorber plates on the thermal efficiency of the flat-plate solar collector," Journal of Thermal Analysis and Calorimetry, vol. 140, no. 3, pp. 1597-1610, 2020.

[30] G. Jilani and C. Thomas, "Effect of thermo-geometric parameters on entropy generation in absorber plate fin of a solar flat plate collector," Energy, vol. 70, pp. 35-42, 2014.

[31] B. Kundu and K.-S. Lee, "Fourier and non-Fourier heat conduction analysis in the absorber plates of a flat-plate solar collector," Solar Energy, vol. 86, no. 10, pp. 3030-3039, 2012.

[32] A. Subiantoro and K. T. Ooi, "Analytical models for the computation and optimization of single and double glazing flat plate solar collectors with normal and small air gap spacing," Applied Energy, vol. 104, pp. 392-399, 2013.

[33] R. Eismann, "Accurate analytical modeling of flat plate solar collectors: extended correlation for convective heat loss across the air gap between absorber and cover plate," Solar Energy, vol. 122, pp. 1214-1224, 2015.

[34] N. Nahar and M. P. Gupta, "Studies on gap spacing between absorber and cover glazing in flat plate solar collectors," International Journal of Energy Research, vol. 13, no. 6, pp. 727$732,1989$.

[35] N. Nahar and H. Garg, "Free convection and shading due to gap spacing between an absorber plate and the cover glazing in solar energy flat-plate collectors," Applied Energy, vol. 7, no. 1-3, pp. 129-145, 1980.

[36] K. Farhana, A. Mahamude, K. Kadirgama, M. Rahman, M. Noor, and D. Ramasamy, "Internal energy analysis with nanofluids in header and riser tube of flat plate solar collector by CFD modelling," IOP Conference Series: Materials Science and Engineering, vol. 469, 2019.

[37] D. Zhang, H. Tao, M. Wang, Z. Sun, and C. Jiang, "Numerical simulation investigation on thermal performance of heat pipe flat- plate solar collector," Applied Thermal Engineering, vol. 118, pp. 113-126, 2017.

[38] L. Wei, D. Yuan, D. Tang, and B. Wu, "A study on a flat-plate type of solar heat collector with an integrated heat pipe," Solar Energy, vol. 97, pp. 19-25, 2013.

[39] Y. Deng, Y. Zhao, W. Wang, Z. Quan, L. Wang, and D. Yu, "Experimental investigation of performance for the novel flat plate solar collector with micro-channel heat pipe array (MHPA-FPC)," Applied Thermal Engineering, vol. 54, no. 2, pp. 440-449, 2013.

[40] S. Jack, J. Parzefall, T. Luttmann, P. Janßen, and F. Giovannetti, "Flat plate aluminum heat pipe collector with inherently limited stagnation temperature," Energy Procedia, vol. 48, pp. 105-113, 2014.

[41] Z. Chen, M. Gu, and D. Peng, "Heat transfer performance analysis of a solar flat-plate collector with an integrated metal foam porous structure filled with paraffin," Applied Thermal Engineering, vol. 30, no. 14-15, pp. 1967-1973, 2010.

[42] L. Zhou, Y. Wang, and Q. Huang, "CFD investigation of a new flat plate collector with additional front side transparent insulation for use in cold regions," Renewable Energy, vol. 138, pp. 754-763, 2019.

[43] H. Kessentini, J. Castro, R. Capdevila, and A. Oliva, "Development of flat plate collector with plastic transparent insulation and low-cost overheating protection system," Applied Energy, vol. 133, pp. 206-223, 2014.

[44] C. S. Meena, S. Meena, and V. Bajpai, "Correlation between absorber plate thickness $\delta$ and collector efficiency factor $\mathrm{F}^{\text {' of }}$ solar flat-plate Collector," Applied Mechanics and Materials, vol. 592-594, pp. 2341-2344, 2014.

[45] S. A. Kalogirou, Solar energy engineering: processes and systems, Academic Press, 2013.

[46] K. Hollands, T. Unny, G. Raithby, and L. Konicek, Free Convective Heat Transfer across Inclined Air Layers, 1976.

[47] S. Klein, "Calculation of flat-plate collector loss coefficients," Solar Energy, vol. 17, no. 1, pp. 79-80, 1975.

[48] D. Close, “A design approach for solar processes," Solar Energy, vol. 11, no. 2, pp. 112-122, 1967.

[49] N. Wijeysundera, "Comparison of transient heat transfer models for flat plate collectors," Sol. Energy;(United States), vol. 21, no. 6, pp. 517-521, 1978.

[50] G. Morrison and D. Ranatunga, "Transient response of thermosyphon solar collectors," Solar Energy, vol. 24, no. 1, pp. 55-61, 1980.

[51] L. S. Sundar, A. Misganaw, M. K. Singh, A. M. Pereira, and A. C. Sousa, "Efficiency, energy and economic analysis of twisted tape inserts in a thermosyphon solar flat plate collector with Cu nanofluids," Renewable Energy Focus, vol. 35, pp. 1031, 2020.

[52] M. Faizal, R. Saidur, S. Mekhilef, and M. A. Alim, "Energy, economic and environmental analysis of metal oxides nanofluid for flat-plate solar collector," Energy Conversion and Management, vol. 76, pp. 162-168, 2013.

[53] L. S. Sundar, E. V. Ramana, Z. Said, V. Punnaiah, K. V. C. Mouli, and A. C. Sousa, "Properties, heat transfer, energy efficiency and environmental emissions analysis of flat plate solar collector using nanodiamond nanofluids," Diamond and Related Materials, vol. 110, p. 108115, 2020.

[54] M. Ameri and M. S. Eshaghi, "A novel configuration of reverse osmosis, humidification-dehumidification and flat plate collector: Modeling and exergy analysis," Applied Thermal Engineering, vol. 103, pp. 855-873, 2016.

[55] S. Chamoli, "Exergy analysis of a flat plate solar collector," Journal of Energy in Southern Africa, vol. 24, no. 3, pp. 8-13, 2013.

[56] H. Kargarsharifabad, M. Behshad Shafii, M. Taeibi Rahni, and M. Abbaspour, "Exergy analysis of a flat plate solar collector in combination with heat pipe," International Journal of Environmental Research, vol. 8, no. 1, pp. 39-48, 2014.

[57] K. Engin, M. Tran, R. Connor, and S. Uhlenbrook, The United Nations World Water Development Report 2018, Nature-Based Solutions for Water; Facts and Figures, 2018.

[58] T. Rajaseenivasan, P. N. Raja, and K. Srithar, “An experimental investigation on a solar still with an integrated flat plate collector," Desalination, vol. 347, pp. 131-137, 2014.

[59] K. Sheeba, P. Prakash, and S. Jaisankar, "Performance evaluation of a flat plate collector coupled solar still system," Energy 
Sources, Part A: Recovery, Utilization, and Environmental Effects, vol. 37, no. 3, pp. 291-298, 2015.

[60] A. Khechekhouche, A. M. Manokar, R. Sathyamurthy, F. A. Essa, M. Sadeghzadeh, and A. Issakhov, "Energy, Exergy Analysis, and Optimizations of Collector Cover Thickness of a Solar Still in El Oued Climate, Algeria," Algeria. International Journal of Photoenergy, vol. 2021, pp. 1-8, 2021.

[61] A. A. Badran, I. A. Al-Hallaq, I. A. E. Salman, and M. Z. Odat, "A solar still augmented with a flat-plate collector," Desalination, vol. 172, no. 3, pp. 227-234, 2005.

[62] M. Feilizadeh, M. K. Estahbanati, K. Jafarpur, R. Roostaazad, M. Feilizadeh, and H. Taghvaei, "Year-round outdoor experiments on a multi-stage active solar still with different numbers of solar collectors," Applied Energy, vol. 152, pp. 39-46, 2015.

[63] S. A. Kumar, P. S. Mohan Kumar, R. Sathyamurthy, and A. M. Manokar, "Experimental investigation on pyramid solar still with single and double collector cover-comparative study," Heat Transfer-Asian Research, vol. 49, no. 1, pp. 103-119, 2020.

[64] Y. A. Al-Molhem and M. A. Eltawil, "Enhancing the doubleslope solar still performance using simple solar collector and floatable black wicks," Environmental Science and Pollution Research, vol. 27, no. 28, pp. 35078-35098, 2020.

[65] M. MohanRai, S. Kumaresan, S. Mathiyazhagan, and Y. Kirubakaran, "The performance analysis of passive solar still combined with flat plate collector," in In 2018 4th International Conference on Electrical Energy Systems (ICEES), Chennai, India, 2018.

[66] A. M. Manokar, M. Vimala, R. Sathyamurthy, A. Kabeel, D. P. Winston, and A. J. Chamkha, "Enhancement of potable water production from an inclined photovoltaic panel absorber solar still by integrating with flat-plate collector," Environment, Development and Sustainability, vol. 22, no. 5, pp. 41454167, 2020.

[67] M. A. Eltawil and Z. Omara, "Enhancing the solar still performance using solar photovoltaic, flat plate collector and hot air," Desalination, vol. 349, pp. 1-9, 2014.

[68] R. Lalitha Narayana and V. R. Raju, "Effect of flat plate collectors in parallel on the performance of the active solar still for Indian coastal climatic conditions," International Journal of Ambient Energy, vol. 40, no. 2, pp. 203-211, 2019.

[69] G. S. Menon, "Parametric factors affecting the performance improvement of a solar still coupled with a flat plate collector," International Journal of Engineering Research, vol. 5, no. 1, pp. 30-33, 2016.

[70] A. Sethi and V. Dwivedi, "Development and life cycle analysis of double slope active solar still with flat plate collector," Journal of Engineering Science \& Technology Review, vol. 7, no. 1, pp. 164-169, 2014.

[71] R. Kerfah, A. Zaaraoui, and B. Noura, "Thermal-economic analysis of modular solar still under Algerian climatic conditions: effect of collector and condensation chamber area," Desalination and Water Treatment, vol. 57, no. 12, pp. 52155221, 2016.

[72] M. Al-harahsheh, M. Abu-Arabi, H. Mousa, and Z. Alzghoul, "Solar desalination using solar still enhanced by external solar collector and PCM," Applied Thermal Engineering, vol. 128, pp. 1030-1040, 2018.

[73] M. Abu-Arabi, M. Al-harahsheh, H. Mousa, and Z. Alzghoul, "Theoretical investigation of solar desalination with solar still having phase change material and connected to a solar collector," Desalination, vol. 448, pp. 60-68, 2018.

[74] Z. A. Kamarul Baharin and M. H. Mohammad, "Experimental investigations on the performance of a single slope solar still coupled with flat plate solar collector under Malaysian conditions," Journal of Mechanical Engineering (JMechE), vol. 6, pp. 16-24, 2018.

[75] H. Soliman, H. Elgohary, M. A. Elmagd, and S. Chowdhury, "Brackish water desalination using solar still with built-in heat exchanger coupled to solar collector," in In 2018 IEEE PES/IAS PowerAfrica, Cape Town, South Africa, 2018.

[76] H. Mousa and M. Abu Arabi, "Desalination and hot water production using solar still enhanced by external solar collector," Desalination and Water Treatment, vol. 51, no. 4-6, pp. 1296-1301, 2013.

[77] R. Poblete, G. Salihoglu, and N. Kamil Salihoglu, "Investigation of the factors influencing the efficiency of a solar still combined with a solar collector," Desalination and Water Treatment, vol. 57, no. 60, pp. 29082-29091, 2016.

[78] S. Balamurugan, N. S. Sundaram, K. P. Marimuthu, and J. Devaraj, "A comparative analysis and effect of water depth on the performance of single slope basin type passive solar still coupled with flat plate collector and evacuated tube Collector," Applied Mechanics and Materials, vol. 867, pp. 195-202, 2017.

[79] S. Rai and G. Tiwari, "Single basin solar still coupled with flat plate collector," Energy Conversion and Management, vol. 23, no. 3, pp. 145-149, 1983. 